\title{
Imaging of Flames in Cement Kilns To Study the Influence of Different Fuel Types
}

Pedersen, Morten Nedergaard; Nielsen, Mads; Clausen, Sønnik; Jensen, Peter Arendt; Jensen, Lars Skaarup; Dam-Johansen, Kim

Published in:

Energy and Fuels

Link to article, DOI:

10.1021/acs.energyfuels.7b01954

Publication date:

2017

Document Version

Peer reviewed version

Link back to DTU Orbit

Citation (APA):

Pedersen, M. N., Nielsen, M., Clausen, S., Jensen, P. A., Jensen, L. S., \& Dam-Johansen, K. (2017). Imaging of Flames in Cement Kilns To Study the Influence of Different Fuel Types. Energy and Fuels, 31(10), 1142411438. https://doi.org/10.1021/acs.energyfuels.7b01954

\section{General rights}

Copyright and moral rights for the publications made accessible in the public portal are retained by the authors and/or other copyright owners and it is a condition of accessing publications that users recognise and abide by the legal requirements associated with these rights.

- Users may download and print one copy of any publication from the public portal for the purpose of private study or research.

- You may not further distribute the material or use it for any profit-making activity or commercial gain

- You may freely distribute the URL identifying the publication in the public portal 


\section{energy fuels:}

Subscriber access provided by DTU Library

\section{Article}

\section{Imaging of Flames in Cement Kilns to Study the Influence of Different Fuel Types}

Morten Nedergaard Pedersen, Mads Nlelsen, Sønnik Clausen, Peter Arendt Jensen, Lars Skaarup Jensen, and Kim Dam-Johansen

Energy Fuels, Just Accepted Manuscript • DOI: 10.1021/acs.energyfuels.7b01954 • Publication Date (Web): 14 Sep 2017

Downloaded from http://pubs.acs.org on September 17, 2017

\section{Just Accepted}

"Just Accepted" manuscripts have been peer-reviewed and accepted for publication. They are posted online prior to technical editing, formatting for publication and author proofing. The American Chemical Society provides "Just Accepted" as a free service to the research community to expedite the dissemination of scientific material as soon as possible after acceptance. "Just Accepted" manuscripts appear in full in PDF format accompanied by an HTML abstract. "Just Accepted" manuscripts have been fully peer reviewed, but should not be considered the official version of record. They are accessible to all readers and citable by the Digital Object Identifier (DOI®). "Just Accepted" is an optional service offered to authors. Therefore, the "Just Accepted" Web site may not include all articles that will be published in the journal. After a manuscript is technically edited and formatted, it will be removed from the "Just Accepted" Web site and published as an ASAP article. Note that technical editing may introduce minor changes to the manuscript text and/or graphics which could affect content, and all legal disclaimers and ethical guidelines that apply to the journal pertain. ACS cannot be held responsible for errors or consequences arising from the use of information contained in these "Just Accepted" manuscripts. 


\title{
Imaging of Flames in Cement Kilns to Study the Influence of Different Fuel Types
}

\author{
Morten Nedergaard Pedersen ${ }^{1} *$, Mads Nielsen ${ }^{2} \dagger$, Sønnik Clausen ${ }^{1}$, Peter Arendt Jensen ${ }^{1}$, Lars \\ Skaarup Jensen ${ }^{2}$, Kim Dam-Johansen ${ }^{1}$ \\ ${ }^{1}$ Department of Chemical and Biochemical Engineering, Technical University of Denmark, \\ Søltofts Plads Building 229, 2800 Kgs. Lyngby, Denmark \\ ${ }^{2}$ FLSmidth A/S, Vigerslev Allé 77, 2500 Valby, Denmark
}

KEYWORDS: Cement rotary kiln burner, alternative fuel, solid recovered fuel, camera 


\begin{abstract}
The cement industry aims to use an increased amount of alternative fuels to reduce production costs and $\mathrm{CO}_{2}$ emissions. In this study three cement plants firing different kinds and percentages of alternative fuel were studied. A specially developed camera setup was used to monitor the flames in the three cement kilns and assess the effect of alternative fuels on the flame. It was found that co-firing with solid recovered fuel (SRF) would delay the ignition point by about 2 meters and lower the intensity and temperature of the kiln flame compared to a fossil fuel flame. This is related to a larger particle size and moisture content of the alternative fuels, which lowers the conversion rate compared to fossil fuels. The consequences can be a lower kiln temperature and cement quality. The longer conversion time may also lead to the possibility of localized reducing conditions in the cement kiln, which can have a negative impact on the clinker quality and process stability. The burner design may alleviate some of the issues encountered with SRF co-firing. At one of the test plants the burner was changed from a design with an annular channel for axial air to a jet design. This proved to be beneficial for an early ignition and improved dispersion of the fuel and led to an increase in cement quality and higher use of SRF.
\end{abstract}

\title{
1. Introduction
}

Since the 90's there has been a growing use of alternative fuels in the cement industry, especially in Europe. ${ }^{1}$ The manufacture of cement is a very energy intensive process and traditionally about $30 \%$ of the production cost is related to fuels. ${ }^{2}$ Alternative fuels are significantly cheaper than conventional fossil fuels giving cement producers an opportunity to reduce their operating costs. 
Additionally, partly biogenic fuels may help reduce the net $\mathrm{CO}_{2}$ emissions from the industry and utilization of refuse derived fuels may limit the need for landfilling. ${ }^{3}$

Alternative fuels can be both solid or liquid and some of the most widely used fuels are old tires, meat and bone meal, and paper and plastics refuse. ${ }^{4}$ Solid Recovered Fuel (SRF) is a common term for the solid non-hazardous fuels derived by mechanical treatment of household or commercial waste. ${ }^{5}$ SRF is a heterogeneous fuel consisting of mainly paper, wood, and plastics as well as some non-combustible materials such as metals and glass. ${ }^{6}$ As a fuel, SRF is characterized by a high heterogeneity with a wide range of physical and chemical properties that affect the combustion in the cement kiln. ${ }^{7}$ Most notably is a high moisture content, typically 1020 wt. $\%^{8,9}$, and large particle size with an equivalent particle diameter in the range $1-30 \mathrm{~mm}^{8,10}$. This increases combustion time and lowers the combustion temperature, compared to the conventional fossil fuels. ${ }^{11,12}$ The increased combustion time can also lead to unconverted fuel particles dropping into the clinker bed, resulting in local reducing conditions in the bed and an increased vaporization of volatile sulfur, which may lead to deposit build-ups in the kiln or preheater. $^{11,13}$

The demand for alternative fuels has driven the development of cement kiln burners in recent years. Today, most new kiln burners are supplied with multiple channels for both pulverized fuels (coal and petcoke) and alternative fuels with larger particle sizes. ${ }^{7,14}$ In addition, the burners include various nozzles for injecting primary air, both with an axial and a swirling motion, in order to control the flame shape. ${ }^{11}$ The primary air and transport air for the fuel typically constitutes $5-15 \%$ of the total combustion air in the cement kiln. ${ }^{16}$ The remaining combustion air is called secondary air, which is preheated to around $1000{ }^{\circ} \mathrm{C}$, by recuperating the heat from the clinker that leaves the kiln. If the secondary air is effectively mixed with the fuel, it 
can help quickly heat and ignite the fuel, which is especially important for alternative fuels, that are harder to ignite than fossil fuels.

The burning zone and the kiln hood of the cement kiln are characterized by a temperature above $1000{ }^{\circ} \mathrm{C}$ and a high dust load, which makes measurements difficult. To monitor the burning zone, cameras can be used. In some cases the cameras can also be used to estimate the burning zone temperature. ${ }^{17}$ This helps the operator control the temperature and proper burning of the clinker. The kiln images can also be used to increase the accuracy of statistic models for prediction of e.g. NOx emissions, since the image intensity reflects the burning zone temperature. ${ }^{18}$ The German Cement Works Association (VDZ) has used kiln cameras to evaluate the burning zone in cement kilns. The method was used to investigate the effect of different fuels and burner settings on the flame. However, only very sparse information on the outcome of the project has been published. ${ }^{7,19}$ Thus, knowledge based on the visual observations of the burning zone is still very limited.

The purpose of this paper is to fill out this knowledge gap. Specifically, camera measurements have been carried out at three different cement plants operating with four different kiln burners and various fractions of alternative fuels. The main goals of this article are:

- Study the impact of alternative fuels using a specially designed camera probe

- Discuss the limitations of alternative fuels firing

- Discuss burner design influence on SRF flames

Hopefully, this analysis will lead to an increased understanding of the impact that alternative fuels will have on the cement kiln operation and highlight some methods to overcome limitations.

\section{Experimental Methods}




\subsection{Equipment}

The cameras used in the cement kilns are typically installed at the back of the kiln hood to be protected from the high temperatures in the kiln. However, the view can be obstructed by large amounts of dust in the kiln hood. ${ }^{18}$ For this work, a portable kiln camera was developed. The camera used was an IDS camera (model number UI-5240CP-C-HQ) with a resolution of 1.3 megapixels and a maximum framerate of 50 frames per second. The camera was placed in an approximately $2 \mathrm{~m}$ long water cooled probe, Figure 1a. The probe was made of concentric stainless steel tubes with cold $\left(\sim 10^{\circ} \mathrm{C}\right)$ cooling water flowing at the center and the hot $\left(\sim 60{ }^{\circ} \mathrm{C}\right)$ return water at the outside. The camera lens was covered by a neutral-density filter, with optical density 1 , to reduce the light intensity and protect the camera from thermal radiation. Compressed air is passed though the probe and helps keep the filter clean from dust and provides additional cooling of the camera. The camera probe can be inserted through the side of the kiln hood close to the burner tip as shown in Figure $1 b+c$. This makes it possible to get a clear image of the burner compared to conventional cameras, which are placed further away from the burner.

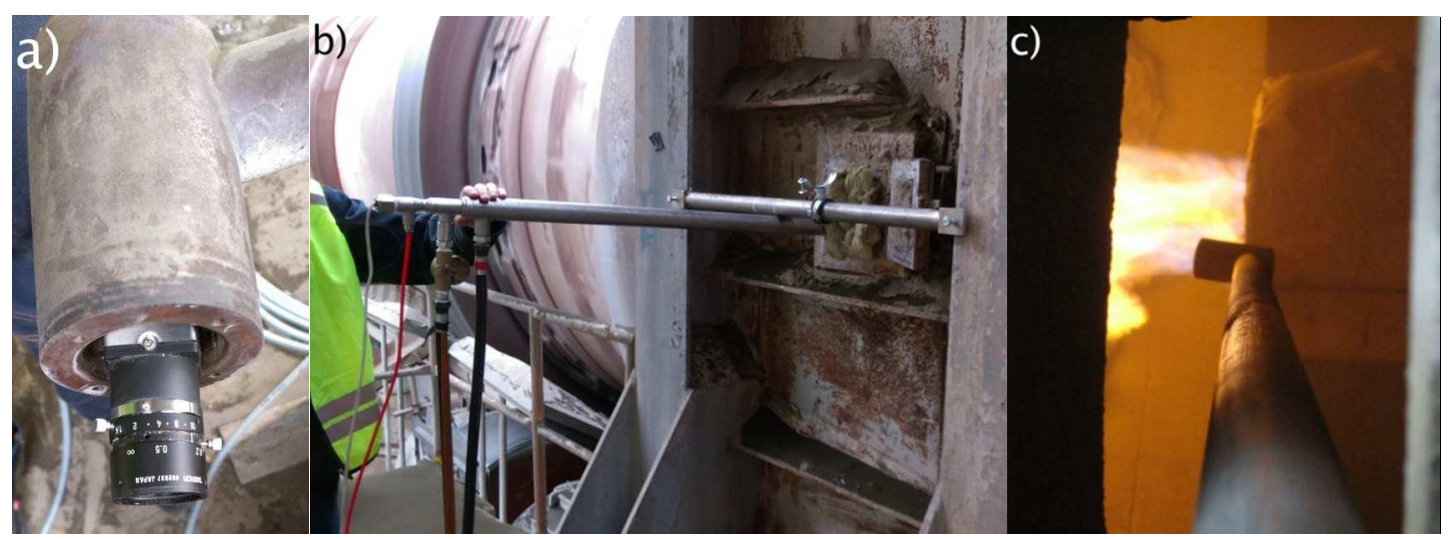

Figure 1: a) The camera inserted in the probe. b) Camera probe inserted though side of kiln hood.

c) Camera probe inserted next to kiln burner.

\subsection{Description of the Cement Plants}


Measurements were carried out at three different European cement kilns all producing ordinary Portland cement clinker. Brief details of the plants are given below. Details of the fuels used at each plant are collected in Table 1.

Plant 1 produces around 3,500 ton clinker per day and has a kiln with a diameter of $5 \mathrm{~m}$ and 77 m length. It is equipped with a 5 stage preheater, in-line calciner, and an FLSmidth HOTDISC device, primarily burning coarse SRF, providing energy to the calciner. Under normal conditions approx. $65 \mathrm{MW}$ is fired in the kiln with $70 \%$ of the energy being from SRF and the remainder from petcoke. The plant maintains a kiln inlet oxygen concentration of 4-5\%.

Plant 2 operates a semi-dry process with a capacity of 4,300 ton of mineralized clinker per day. It is equipped with a 2-string 5 stage preheater and in-line calciner, where the main fuel is SRF supplemented by coal. The kiln has a diameter of $4.75 \mathrm{~m}$ and is $74 \mathrm{~m}$ long. In the kiln, the fuel energy input is $70 \mathrm{MW}$ with the main fuel being a mix of $75 \%$ coal and $25 \%$ petcoke. As alternative fuel SRF or granulated tires can be used in amounts of up to approximately 10 or 30 $\%$ of the energy input, respectively. The oxygen concentration at the kiln inlet is 5-6\%.

Plant 3 has a clinker capacity of 3,100 ton per day in a kiln of $5 \mathrm{~m}$ in diameter and length of 68 m. The plant has a 5-stage preheater, an in-line calciner, and FLSmidth HOTDISC, burning primarily whole tires and coarse SRF, $<120 \mathrm{~mm}$. In the kiln, petcoke is used as the main fuel. The plant uses several types of alternative fuels in the kiln with the largest fraction being SRF and smaller amounts of dried sewage sludge or waste oil contributing up to $50 \%$ of the energy in the kiln. The total energy input of fuel in the kiln is around $65 \mathrm{MW}$. Due to defunct equipment, the oxygen concentration at the kiln inlet was not monitored during the measurement campaign; however, it is likely around $5 \%$. 
The three plants have different burners from major burner suppliers. In plant 1 the burner was recently changed to the JETFLEX burner from FLSmidth. This allowed a comparison of two different burners at the same site. The JETFLEX Plus burner from FLSmidth is presented in Figure 2. In the center of the burner a large pipe for solid alternative fuels is placed and below is an additional channel, which is used to insert a lance for oxygen enrichment at Plant 1 . The center is surrounded by an annular channel with vanes for swirl air, followed by annular channels for petcoke and then gas. On the outside are 20 nozzles for the axial air. The nozzles can turn individually $360^{\circ}$ and further help to shape the flame. The burner was a retro-fit and the coal and gas channels were reused from the existing burner installation at the site.

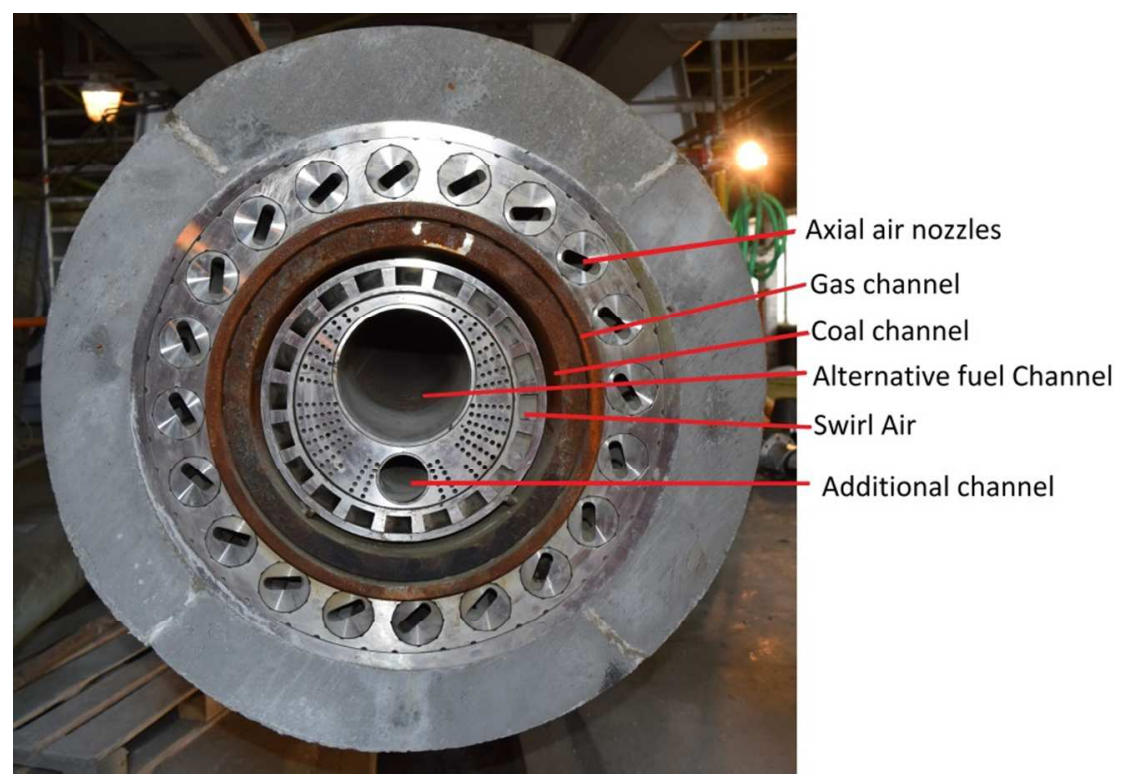

Figure 2: The Jetflex Plus burner from FLSmidth installed at Plant 1.

Details of the fuels used at the three plants are shown in Table 1. The analysis of the fuel is on a wet basis. The samples for coal and petcoke listed for Plant 2 and 3 are taken from the stock at the respective plants. Thus, the moisture content is relatively high compared to that of Plant 1 . Before being used in the kiln the solid fossil fuels are grinded in mills to a particle size $<100 \mu \mathrm{m}$ 
and dried to a moisture content of approx. $2 \%$ at Plant 2 and $0.6 \%$ at Plant 3 . An example of the SRF used at the different plants is given in Figure 3.

Table 1: Properties of the fuels utilized at the cement plants. Data are on an as received basis. Moisture and ash in coal and petcoke depends on sampling before (Plant 2 and 3) or after milling (Plant 1).

\begin{tabular}{|c|c|c|c|c|c|c|c|c|c|}
\hline & \multicolumn{2}{|l|}{ Plant 1} & \multicolumn{4}{|c|}{ Plant 2} & \multicolumn{3}{|l|}{ Plant 3} \\
\hline & Petcoke & SRF & Coal & Petcoke & SRF & $\begin{array}{l}\text { Granulated } \\
\text { tires }\end{array}$ & Petcoke & SRF & $\begin{array}{l}\text { Sewage } \\
\text { Sludge }\end{array}$ \\
\hline $\begin{array}{l}\mathrm{LHV} \\
(\mathrm{MJ} / \mathrm{kg})\end{array}$ & 32.3 & 17.5 & 25.2 & 30.7 & 18.7 & 34.4 & 31.9 & 19.3 & 13.8 \\
\hline $\begin{array}{l}\text { Moisture } \\
(\mathrm{wt} \%)\end{array}$ & 0.9 & 19.8 & 11.9 & 8.8 & 17.3 & 1.5 & 6.1 & 21.5 & 9.2 \\
\hline $\begin{array}{l}\text { Ash } \\
(\mathrm{wt} \%)\end{array}$ & 7.2 & 15.5 & 6 & 0.58 & 12.5 & 6 & 1.3 & - & 28.2 \\
\hline $\begin{array}{l}\text { Volatiles } \\
(\mathrm{wt} \%)\end{array}$ & 13.8 & 45.9 & 34.0 & 9.8 & - & - & 11.8 & - & - \\
\hline $\begin{array}{l}\text { Sulfur } \\
(\mathrm{wt} \%)\end{array}$ & 3.4 & 0.5 & 0.44 & 5.89 & - & - & 5.5 & 0.29 & - \\
\hline $\begin{array}{l}\text { Chlorine } \\
(\mathrm{wt} \%)\end{array}$ & 0.04 & 0.66 & 0.02 & $\begin{array}{l}44 \\
(\mathrm{ppm})\end{array}$ & - & - & - & 1.0 & - \\
\hline $\begin{array}{l}\text { Particle } \\
\text { Size }\end{array}$ & $\begin{array}{l}3.5 \%> \\
90 \mu \mathrm{m} \\
\text { sieve }\end{array}$ & $\begin{array}{l}<30 \\
\mathrm{~mm}\end{array}$ & $\begin{array}{l}13 \% \\
>90 \\
\mu \mathrm{m} \\
\text { sieve }\end{array}$ & $\begin{array}{l}13 \%> \\
90 \mu \mathrm{m} \\
\text { sieve }\end{array}$ & - & - & $\begin{array}{l}3.5 \%> \\
90 \mu \mathrm{m} \\
\text { sieve }\end{array}$ & $\begin{array}{l}\text { Max } \\
30 x 30 \times 2 \\
\operatorname{mm}\end{array}$ & - \\
\hline $\begin{array}{l}\text { Typical } \\
\text { use (\% } \\
\text { or } \mathrm{t} / \mathrm{h})\end{array}$ & $\begin{array}{l}20-40 \\
\% \\
\text { energy }\end{array}$ & $\begin{array}{l}60-80 \\
\% \\
\text { energy }\end{array}$ & 7 & 2 & 1.5 & 3 & 4 & 5 & 1 \\
\hline
\end{tabular}




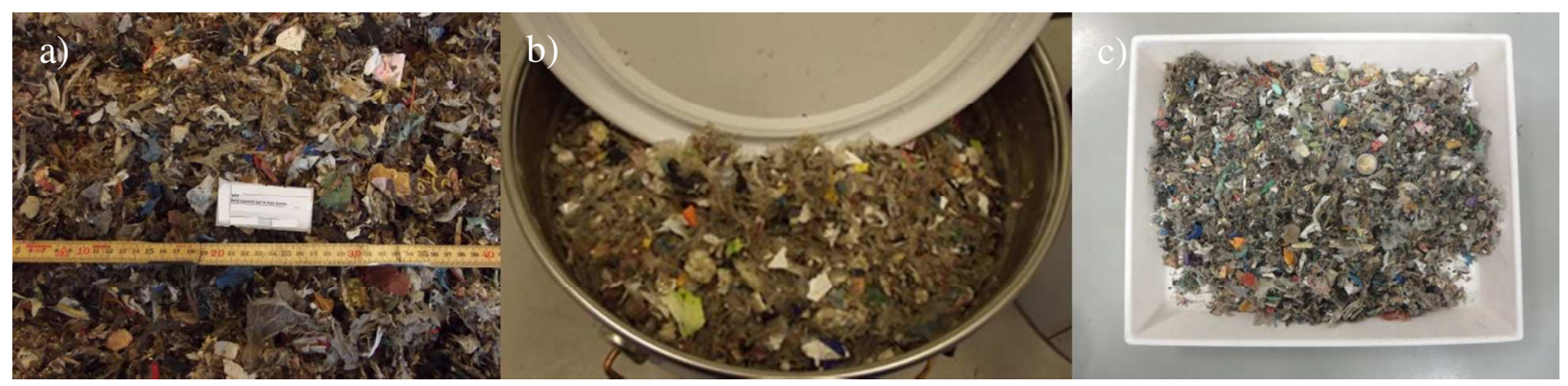

Figure 3: SRF used at plant 1 (a), Plant 2 (b), and Plant 3 (c).

Another important aspect of how the burners operate, is the use of primary air which is used to shape the flame. ${ }^{7}$ This is typically divided into axial air, which adds axial momentum to the flame, and swirl (radial) air, which may create internal recirculation zones and stabilize the flame. $^{20,21}$ Transport air is also used to pneumatically convey the fuel through the burner. In addition air is used to cool the burner, often called central air, and occasionally some air can be used to disperse alternative fuels. ${ }^{16}$ Table 2 contains an overview of the primary air used at the kiln burners at the three different cement plants.

Table 2: Amount and pressure of primary air typically used in the burners at the three cement plants. Plant 3 uses a burner with no separate swirl air channel.

\begin{tabular}{|l|l|l|l|l|}
\hline & \multicolumn{2}{|l|}{ Plant 1 } & Plant 2 & Plant 3 \\
\hline & Old Burner & New Burner & & \\
\hline Primary Air Amount $\left(\mathrm{m}^{3} / \mathrm{h}\right)$ & 12000 & 12000 & 6200 & 6600 \\
\hline Axial Air Pressure (mbar) & 230 & 210 & 300 & 220 \\
\hline Swirl Air Pressure (mbar) & 240 & 150 & 40 & - \\
\hline Other Air Pressure (mbar) & 50 & 10 & 70 & 100 \\
\hline Transport Air Amount $\left(\mathrm{m}^{3} / \mathrm{h}\right)$ & 4000 & 4000 & 4400 & 4200 \\
\hline
\end{tabular}




\begin{tabular}{|l|l|l|l|l|}
\hline $\begin{array}{l}\text { Fraction Primary Air } \\
(\% \text { of total combustion air })\end{array}$ & $\sim 20$ & $\sim 20$ & $\sim 13$ & $\sim 10$ \\
\hline
\end{tabular}

\section{Results and Discussion}

The main objective of this study has been to get an increased understanding of the effect that alternative fuels have on the flame in the cement kiln based on visual observations. Several hours of video footage under different operating conditions have been recorded at the cement plants included in this study. In the following sections those hours of video recordings are condensed into a few representative images of the flames. In addition, example videos are available as supporting material.

The sketch in Figure 4a shows how the camera is inserted though the side of the kiln hood and the approximate field of view into the kiln. The Image in Figure $4 \mathrm{~b}$ shows the typical view seen with the camera. On the right side of the image the burner tip is seen. The fuel is injected though the burner forming a dark flame plume, which expands and becomes wider as it moves away from the burner. At some point the fuel is ignited, giving a bright high intensity region. Below the fuel plume, the hot clinker bed at the bottom of the kiln can be seen. Above the fuel plume the opposite kiln wall can be observed. It is slightly darker than the clinker, indicating a lower temperature. The camera can be moved around, which will change the view. For instance, the camera can be turned downwards under the fuel plume, to observe if fuel drops to the clinker bed. In the following the ignition point is defined as the distance from the burner where a sudden change in image intensity is observed. The distance will be measured along the center of the fuel plume. In Figure $4 \mathrm{~b}$ this is seen as the point where the dark fuel plume changes color to bright 
yellow/white. As seen in the image this occurs earlier at the top and bottom of the flame plume compared to the center, but the center value will be used as the ignition point.
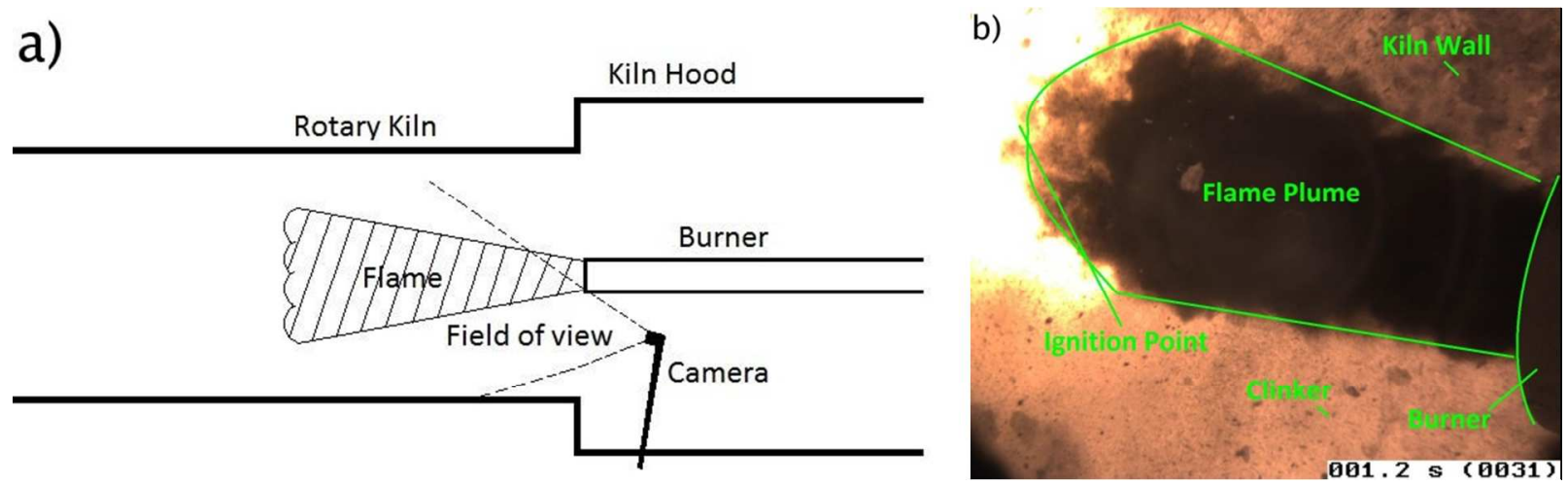

Figure 4: a) Sketch of the camera view (top view). b) Explanation of camera view.

The cement flame is characterized by a high degree of turbulent motion, which means that it is constantly fluctuating. In addition, there can be various amounts of dust in the kiln, which can influence the visibility. The images in Figure 5a-c are taken 0.4 seconds apart and show how the flame ignition point and plume width change. To limit the effect of the short term variations an average frame can be produced. The greyscale image in Figure $5 \mathrm{~d} s$ has been averaged over 5 seconds. This concept will be used through the remainder of the paper, where images in color are single frames from the recorded videos and images in greyscale are averaged over 5 seconds. In the images, the distance to the burner tip has been estimated, with the numbers indicated in meters. This will help estimate how much e.g. the ignition point is changed by different fuel types. The description of how the distances are estimated is described in the supporting material. 
a)

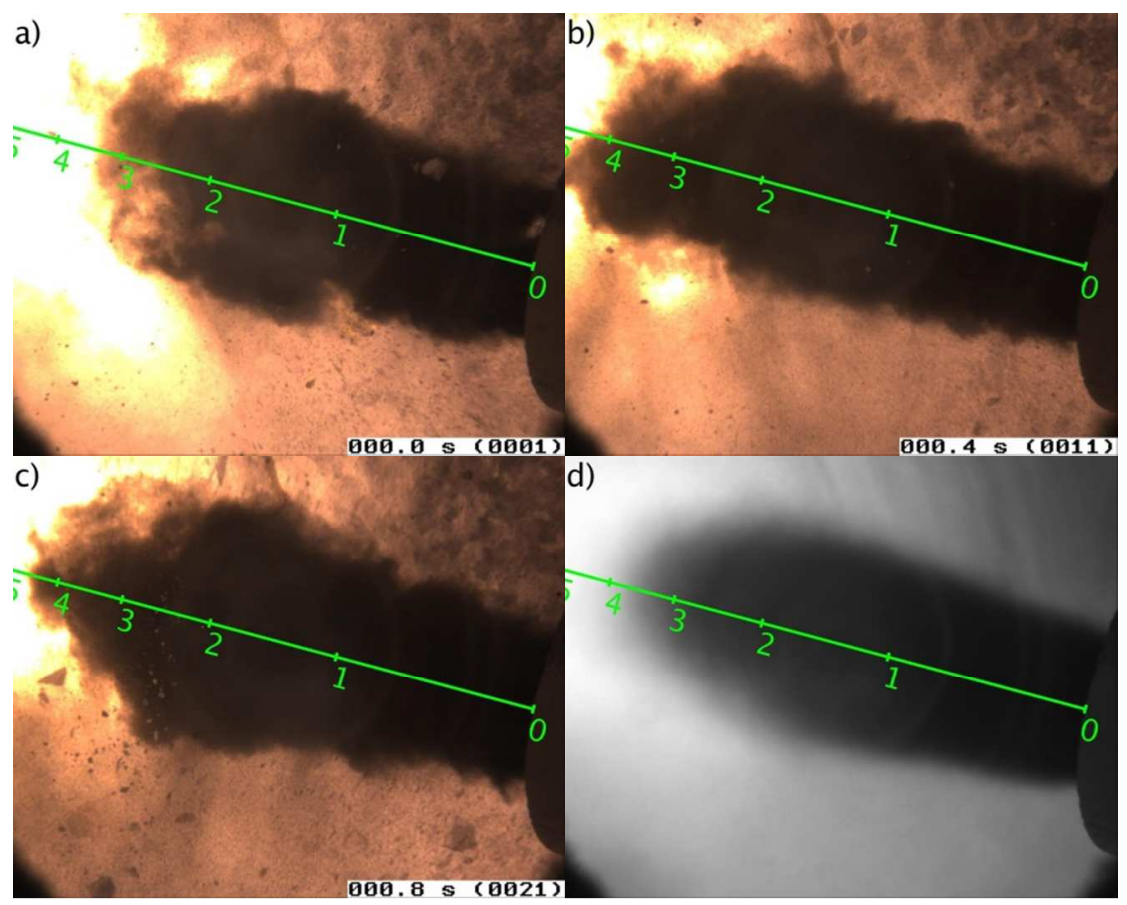

Figure 5: a-c) Images taken 0.4 seconds apart showing the fluctuations in the kiln flame. d) Frame averaged over 5 seconds. Images from Plant 1 during full petcoke load.

\subsection{Results from Plant 1}

\subsubsection{Petcoke fired flame}

A wholly petcoke fired flame from the old and new burners used at Plant 1 is seen in Figure 6. First of all it is noticed that the petcoke is ignited relatively far from the burner with the earliest ignition approximately 3 meters from the burner tip. This is generally one of the issues of using petcoke in the cement kiln and is caused by the low volatile content of petcoke compared to coal, cf. Table $1 .^{22,23}$ It is seen that the new burner (Figure $6 c+d$ ) ignites the petcoke earlier than the old burner (Figure $6 a+b)$. As shown in Figure 5 the ignition point can fluctuate more than 1 meter in a short time, but on average the new burner has an ignition point between 3 and 4 meters from the burner, while the ignition point of the old burner is more than 4 meters away, outside the frame of the image. The earlier ignition is caused by a more effective entrainment of 
the hot secondary air into the fuel stream, which allows for a faster heat up of the fuel. This is primarily achieved by three measures on the new burner. The swirl channel is located inside the coal channel on the new burner, while it was located on the outside on the old burner. This has a tendency to push the fuel outwards, where it meets with the hot secondary air. ${ }^{20}$ In addition, the swirler channel vanes are angled more, which gives a higher tangential velocity to induce swirling motion and increase mixing. Lastly, the axial air jets of the new burner will allow for an increased secondary air entrainment compared to an annular air channel. ${ }^{11,24}$ It is generally thought to be beneficial with a high amount of entrainment and early ignition as this gives a short high temperature flame, where heat can easily be transferred to the clinker. An early ignition can also help reduce $\mathrm{NO}_{\mathrm{x}}$ since less oxygen has had time to entrain into the flame. ${ }^{25,21}$ On the other hand, when the swirl channel is located inside the petcoke channel, the fuel is pushed out into more oxygen rich conditions, which may increase the $\mathrm{NO}_{\mathrm{x}} \cdot{ }^{20,25,21}$ 


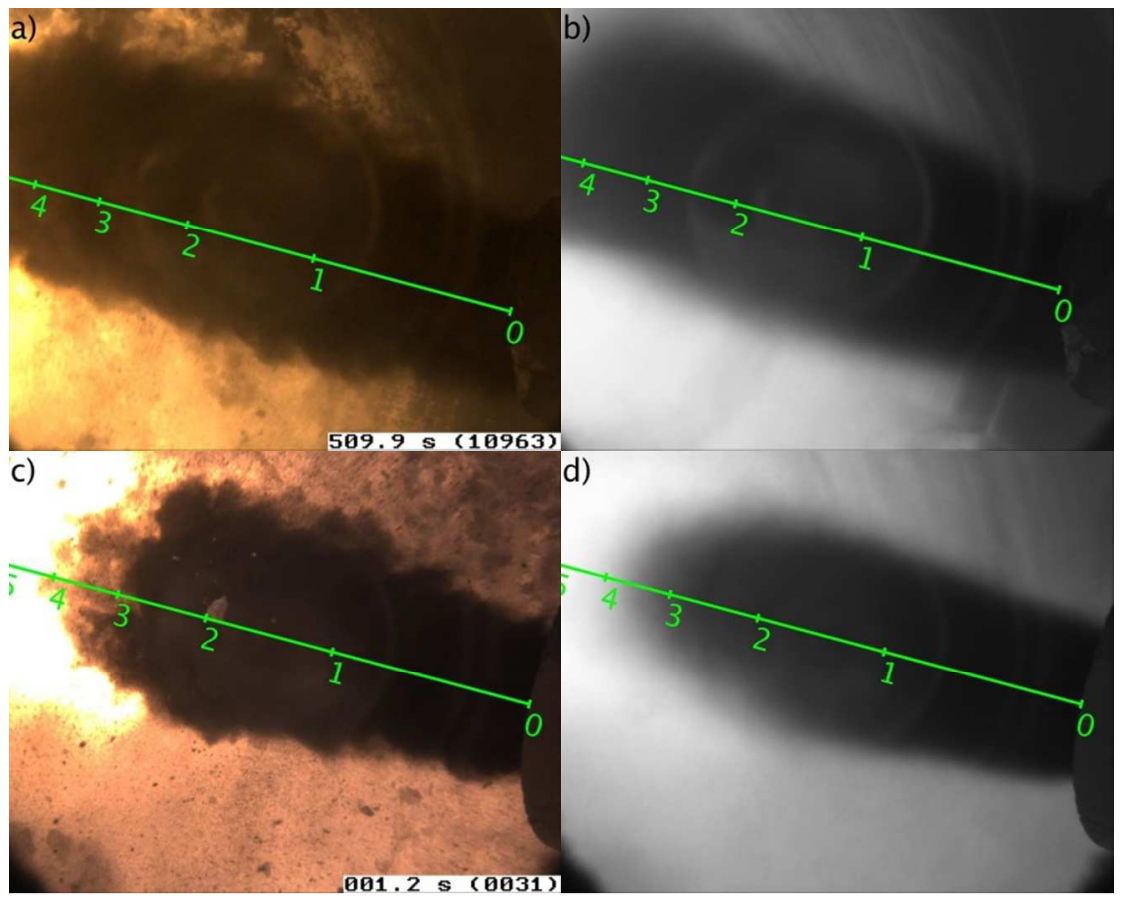

Figure 6: Images during full petcoke firing of old burner $(a+b)$ and new burner $(c+d)$. Old burner operating with 250 mbar swirl air pressure and new burner operating with 190 mbar swirl air pressure. Images from Plant 1.

\subsubsection{Petcoke and SRF co-firing}

Most of the time Plant 1 operates with a co-firing scenario where $60-80 \%$ of the energy input is supplied by SRF. The ratio between the fuels is used to control the burning zone temperature and will typically be influenced by quality variations in the SRF. I.e. if the moisture content of the SRF increases and the heating value decreases, it will be necessary to increase the amount of petcoke to keep the temperature constant. Images of the co-firing case are seen in Figure 7. The flame plume is narrower and lighter in color compared to the full petcoke cases shown in Figure 6 and the ignition point of the flames is moved further away from the burner. For the old burner, Figure $7 \mathrm{a}+\mathrm{b}$, the ignition is still outside the image frame, more than 5 meters from the burner tip. For the new burner, Figure $7 c+d$, the ignition point is around 5 meters from the burner, which is 
2 meters further away than when only petcoke was fired. The difference is caused by SRF, which delays the ignition due to a longer heating time, caused by a larger particle size and high moisture content. The narrower fuel plume is caused by a lower amount of petcoke being used than in Figure 6. The petcoke is added though an annular channel close to the edge of the burner, while the SRF is added through a central pipe, cf. Figure 2. This causes the petcoke to more readily expand, which results in a wider flame plume.

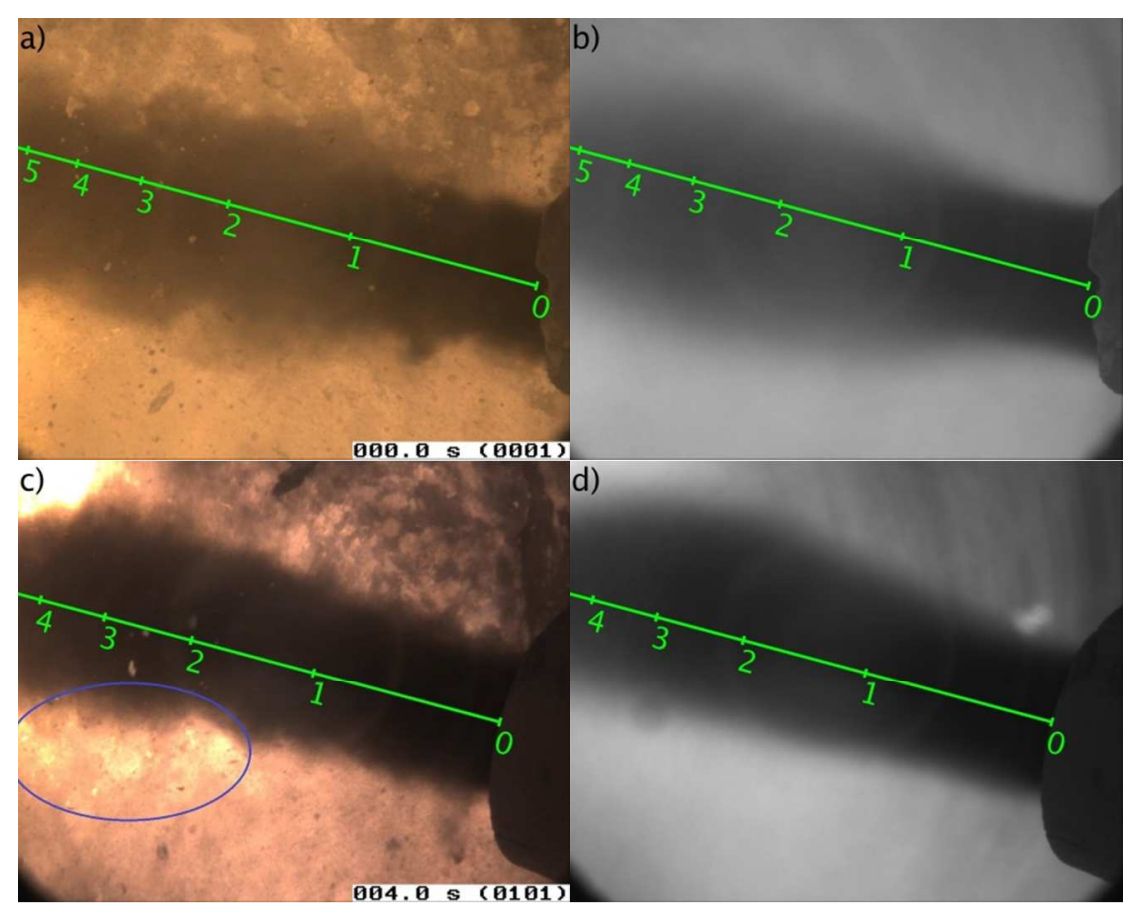

Figure 7: Images during co-firing of petcoke and SRF of old burner $(a+b)$ and new burner $(c+d)$. The old burner operates with $80 \%$ energy by SRF and 240 mbar swirl air pressure. The new burner operates with $70 \%$ energy by SRF and 180 mbar swirl air pressure. Images from Plant 1.

In the lower left corner of Figure 7c some burning particles can be seen. These are SRF particles whirled out of the flame due to the swirling flow. When they enter the hot secondary air, it is possible to ignite the particles faster than in the cold fuel plume. The amount of SRF that is whirled out of the flame can to some extent be controlled by the swirl, as shown in Figure 8. 
Here a flame with 180 mbar swirl air pressure is compared to one with 100 mbar swirl air. With the increase in pressure, the exit flow velocity of the tangential swirl air is increased, which increases the angular momentum and the swirl intensity. ${ }^{26}$ Burning SRF particles can be seen as small specks of light on the darker background, and have also been highlighted by blue circles. With the high amount of swirl more SRF particles are seen to burn outside the main flame. Almost twice as many particles are marked in Figure 8a compared to Figure 8b. It is unfortunately not certain whether this can be considered as a representative measure of the amount of SRF burning outside the flame. Thus, if a specific cement plant is vulnerable to particles burning in the clinker, i.e. local reducing conditions; it may be beneficial to lower the swirl. However, this will also have a negative effect on the mixing and the flame intensity, causing the ignition to take place further inside the kiln. This is also shown in this image, where the flame intensity in the upper left corner is much higher with the high swirl. The images in Figure 8 are recorded with a different view than previous images. The camera has been turned to look further down the kiln, and the tip of the burner is outside the image on the right side. It has not been possible to estimate the distance in these images, since no reference size is present. In the previous pictures the burner is used as size reference.

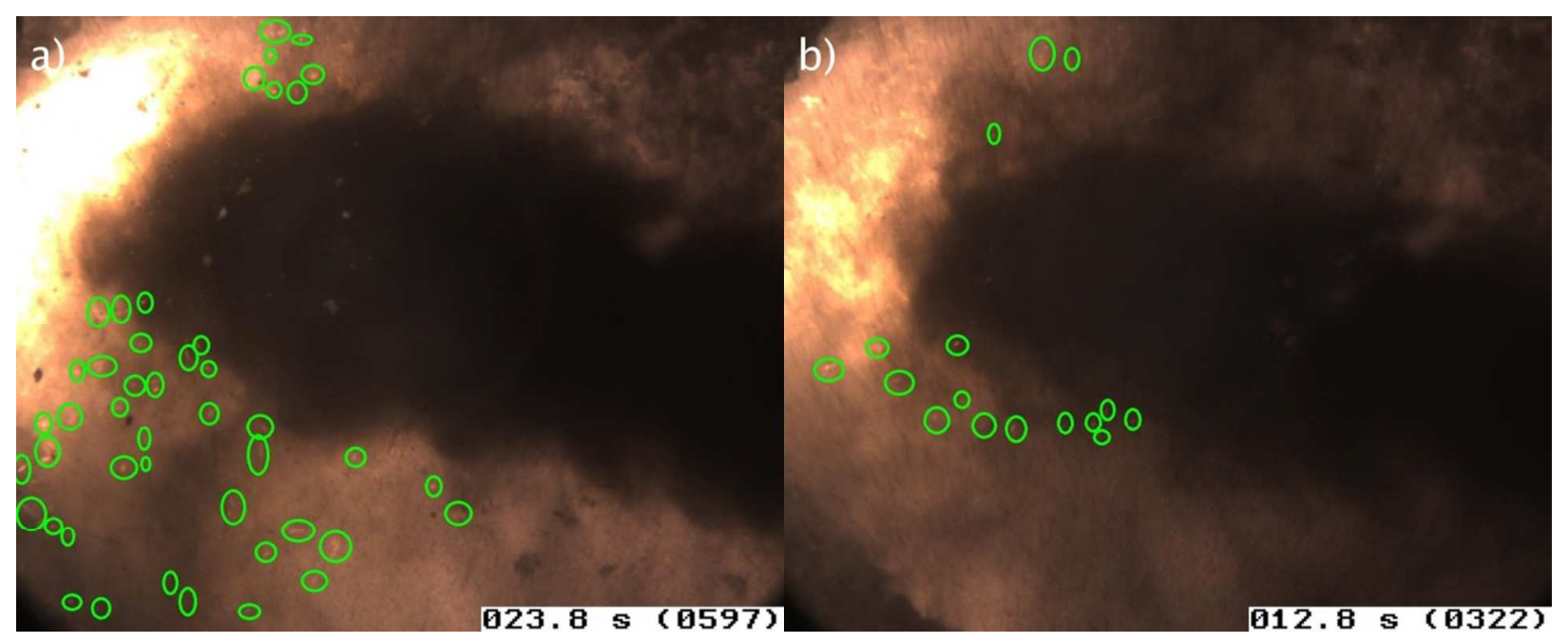


Figure 8: Co-firing with the new burner at Plant 1 with 180 (a) and 100 (b) mbar swirl air pressure. Images from Plant 1. Burning SRF particles are highlighted by green circles. Distances are not indicated in the figure since no reference size is present.

\subsubsection{SRF fired flame}

The petcoke that is fired in an annular channel around the SRF blocks for a clear view of the SRF flow and combustion behavior. At plant 1 it was possible to turn off the petcoke for a brief period to study how the SRF behaves when injected into the kiln. In Figure 9 these results are presented. A small amount of residual petcoke is present in the annular channel in the pictures of the old burner (Figure 9a-c). The fuel flow from the old burner is characterized by a low degree of dispersion, where the fuel follows the initial injection trajectory. The low degree of fuel dispersion is detrimental to the combustion of the fuel, since it creates a dense cold core in the flame, which inhibits ignition. When the camera view is changed, cf. Figure 9c, it can be seen how the particles continue far inside the kiln without being ignited. It can be assumed that the particles will eventually land in the clinker bed largely unconverted. The new burner is better at dispersing the SRF particles. After an initial $\sim 1 \mathrm{~m}$ where the SRF is densely packed, it starts to spread out. Some particles still tend to follow the injection trajectory, which can be observed in the averaged image of Figure 9f. This is primarily caused by denser lumps of particles, which are difficult to disperse. One such lump can be tracked in Figure 9d and e, which are taken 0.3 seconds apart. These lumps are most likely caused by the feeding system. In this case the SRF is fed through a rotary feeder located 20 meters behind the burner. The feeder rotates and its compartments are blown clean by the conveying air, which tends to generate the fuel lumps, which can be observed at the burner tip. With a more uniform feeding, it would likely be easier to disperse the particles properly. 


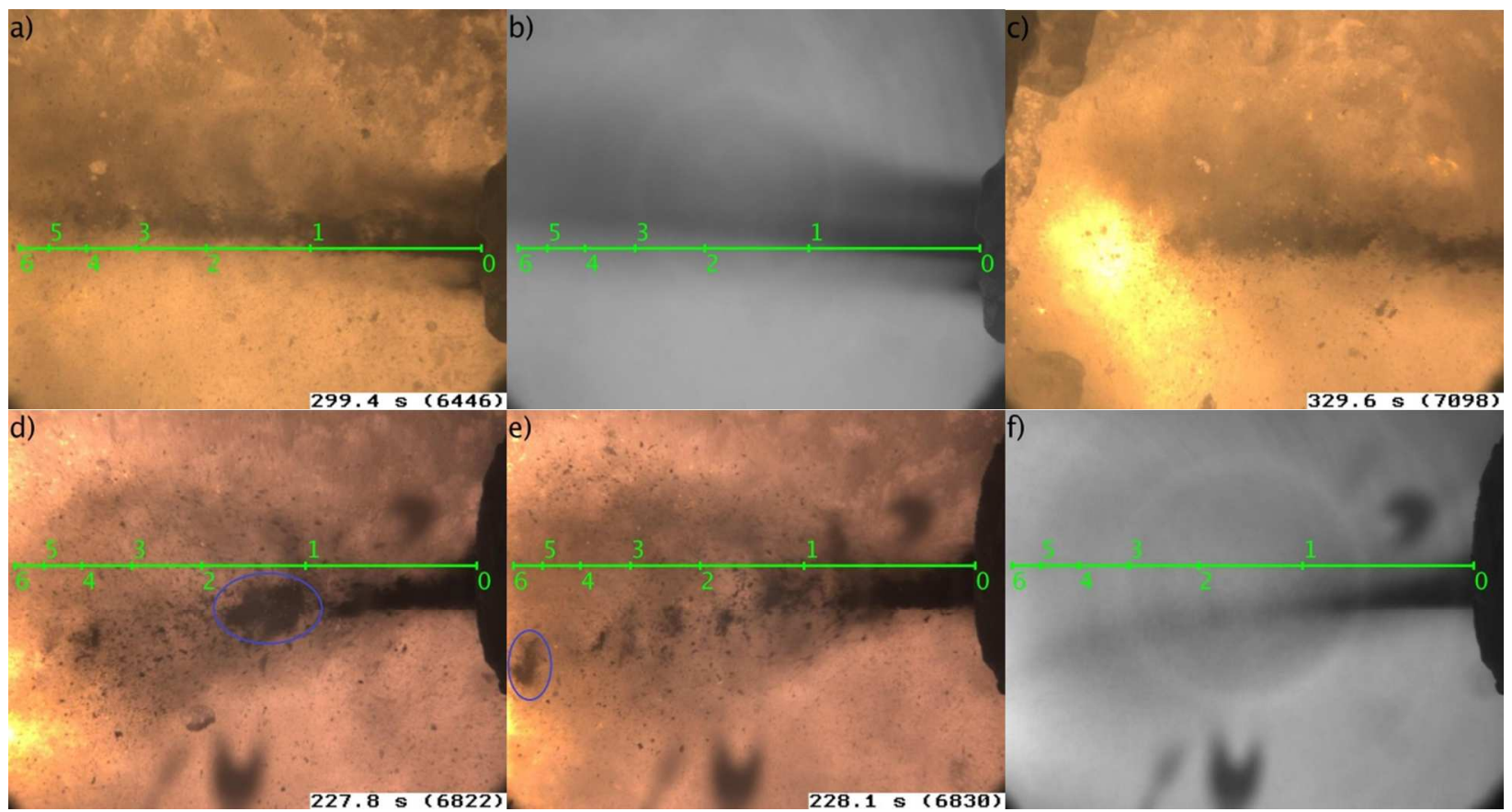

Figure 9: Images during $100 \%$ SRF firing for old burner $(a+b+c)$ and new burner $(d+e+f)$. The old burner operates a swirl air pressure of 240 mbar. The new burner with a swirl air pressure of 150 mbar. The camera has been turned further downstream in image $\mathrm{c}$, than in the other images.

The total primary air flow for the two burners is the same at approx. $12,000 \mathrm{~m}^{3} / \mathrm{h}$, but the old burner operates at a significantly higher swirl pressure, 240 mbar compared to 150 mbar. This should allow for a higher tangential velocity and the possibility to obtain a higher angular momentum. However, as evident from the images, the swirl is not utilized to affect the flow of SRF. The design of the new burner with a higher angle of the swirl vanes and the channel located close to the SRF seems highly beneficial for the dispersion of SRF in the kiln.

The main advantage of the higher dispersion of particles is a better mixing with the hot secondary air, which leads to an earlier ignition. Some burning particles can be observed in the top and bottom left corners of the images in Figure 9d and e, when the fuel leaves the cold fuel core. The high degree of fuel spreading also causes some of the fuel particles to be whirled out of 
the flame by the centrifugal forces generated by the swirl. In the cement industry, this is traditionally viewed as a negative thing, since it can lead to local reducing conditions in the kiln bed, which promotes brown clinker, stabilization of belite, and increased sulfur evaporation. ${ }^{13,27-}$ ${ }^{30}$ However, this does not appear to be a specific issue at the plant, where, generally, the quality of the clinker is good, with an alite content above $65 \mathrm{wt} \%$. Brown clinker and build-ups have not been reported by the plant operators, which suggests that the plant is insensitive to reducing conditions. In fact, it may be beneficial to purposely spread the fuel near the kiln outlet, where the oxygen concentration is high and the clinker nodules are already formed, since the evaporation of sulfur will be limited by the smaller surface area for evaporation. ${ }^{27}$ In addition, the energy contained in the fuel will be released before the clinker burning zone and contribute to increasing the temperature here, presumably yielding an increased cement quality. Experiments carried out by Nørskov ${ }^{16}$ have shown that injecting alternative fuels too far into the kiln limits the possible substitution in the cement kiln, and just substitutes calciner firing. This will be discussed in further detail later.

Table 3 contains measures of the key parameters that the burner performance is measured on. Most importantly, with the new burner it was possible to achieve an increased use of SRF while the petcoke consumption was lowered, resulting in a higher energy share of SRF. At the same time the clinker alite content, which is a measure of the quality, increased. Operation of the old burner was supported by oxygen enrichment at the burner where $460 \mathrm{Nm}^{3} / \mathrm{h}$ of oxygen was used to increase the combustion quality. With the new burner this was not necessary, and the oxygen was only used on a few test days. The clinker production was slightly lower with the new burner. In conclusion, the changes in the design were shown to give an earlier ignition and increased dispersion of SRF, resulting in an improved performance. 
Table 3: Comparison of key operating parameters for the old and new kiln burners at Plant 1. Values are averages for one month of operation. Ignition point data from Figure 6 and Figure 7.

\begin{tabular}{|l|l|l|l|l|l|}
\hline & $\begin{array}{l}\text { SRF Energy } \\
\text { Share }\end{array}$ & $\begin{array}{l}\text { Clinker } \\
\text { Alite } \\
\text { Content }\end{array}$ & $\begin{array}{l}\text { Oxygen } \\
\text { enrichment } \\
\text { at burner }\end{array}$ & $\begin{array}{l}\text { Clinker } \\
\text { Production }\end{array}$ & Ignition Point \\
\hline$\%$ & $\mathrm{Wt} \%$ & $\mathrm{Nm}^{3} / \mathrm{h}$ & $\mathrm{t} / \mathrm{h}$ & $\mathrm{m}$ \\
\hline $\begin{array}{l}\text { Old } \\
\text { Burner }\end{array}$ & 62.7 & 65.3 & 460 & 147 & $\begin{array}{l}\text { Petcoke: }>4 \mathrm{~m} \\
\text { Co-firing: }>5 \mathrm{~m}\end{array}$ \\
\hline $\begin{array}{l}\text { New } \\
\text { Burner }\end{array}$ & 67.5 & 67.5 & 37 & 144 & Petcoke: $3-4 \mathrm{~m}$ \\
Co-firing: $5 \mathrm{~m}$
\end{tabular}

\subsection{Results from Plant 2}

The fuel dosing during the test day at Plant 2 and the kiln drive power consumption are shown in Figure 10. The power consumption of rotating the kiln is often used as a relative measure of the kiln tempearture. ${ }^{31}$ As the temperature rises, more material will melt inside the kiln, which will make it more difficult to rotate the kiln, increasing the kiln torque and power consumption. However, the power will also be influenced by other factors such as the amount of material in the kiln or the rotational speed.

Before 13:00, the kiln was fired exclusively with a mix of coal and petcoke. At 13:15 the SRF amount was increased to $1.5 \mathrm{t} / \mathrm{h}$. This level can normally be tolerated at plant without issues. Just after 16:00 the SRF firing was increased to $4.5 \mathrm{t} / \mathrm{h}$ for 20 minutes, while the coal was reduced to $7.5 \mathrm{t} / \mathrm{h}$. There are generally large fluctuations in the kiln drive power consumption during the day 
even though the kiln firing is kept constant. This is caused by changes in the kiln feed and calciner firing, which are not shown here. However, as the SRF is increased to $4.5 \mathrm{t} / \mathrm{h}$ there is a sudden large drop in the kiln power, which is clear when observing Figure 10b, where the gradient of the power consumption is shown. A rapid increase is seen as the SRF is reduced back to $1.5 \mathrm{t} / \mathrm{h}$. The drop in power consumption can indicate a lower temperature in the kiln, which will lower the cement quality. The kiln operator also reported an increased amount of dust in the cooler with increased SRF. This may indicate increased sulfur volatilization caused by local reducing conditions.
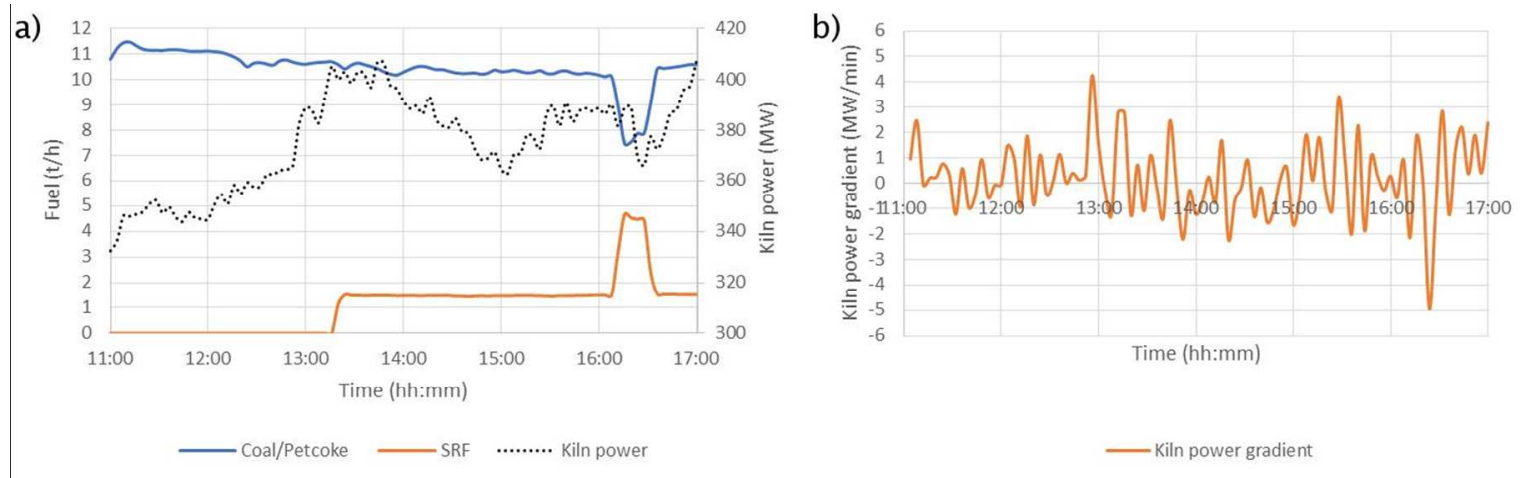

Figure 10: a) Fuel dosing of coal/petcoke, and SRF and the kiln drive power consumption (secondary axis) during the test day. b) Gradient of the power consumption. Data from Plant 2.

\subsubsection{Fossil fuel fired flame}

The fossil fired flame from Plant 2 is shown in Figure 11. The plant fires a mix of $75 \%$ of coal and $25 \%$ petcoke. The flame is seen to ignite very close to the burner, around 1-2 meters from the tip, compared to the 3-4 meters at Plant 1, which was shown in Figure 6. This is generally due to the high volatility of the coal, compared to petcoke, cf. Table 1 . The flame is seen to ignite in an uneven pattern, which is clear in Figure 11a and c. The burner is designed with a number of axial air jets surrounding the coal inlet. Four larger gaps are made between some of 
the jets, which allows for a place where additional secondary air can entrain into the fuel jet. This heats up the fuel quickly and ignites it. The three images in Figure 11 underline the turbulent nature of the kiln flame, which constantly fluctuates. In Figure 11a, the ignition point is very close to the burner, while it is more removed in Figure $11 \mathrm{~b}$.

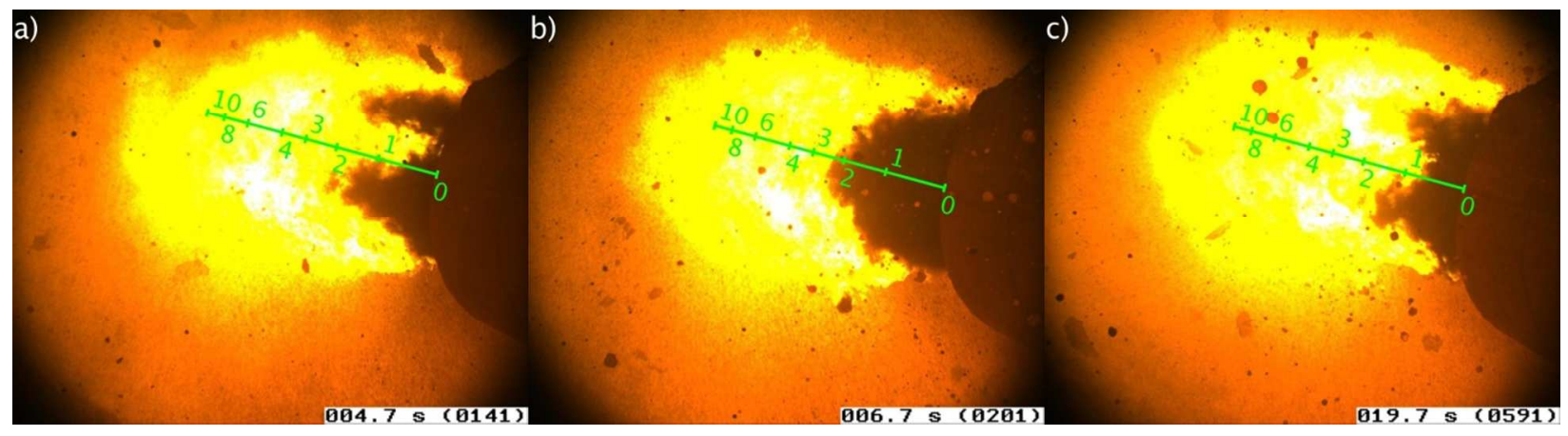

Figure 11: Images of the coal/petcoke fired flame with $10.5 \mathrm{t} / \mathrm{h}$ coal/petcoke. Images from Plant 2.

\subsubsection{Co-fired flame}

Example images from the recorded videos with SRF co-firing are seen in Figure 12. The ignition point is between 2-4 meters from the burner, which is 2 meters further away than in the coal fired flame. The flame also appears less intense, indicating a lower flame temperature. This is a similar observation to the co-firing case seen at Plant 1 and is likely caused by a reduction in the coal amount and a longer heating and burning time of the larger SRF particles, which delays the ignition.

The flame appears to ignite earlier at the bottom. This may be due to high radiation from the hot clinker below the flame, which gives an uneven heating of the fuel. It may also be caused by the flow of the secondary air from the clinker cooler, which is mainly coming from below. ${ }^{32}$ The ignition at the side is no longer as pronounced as for the coal fired flame, although it is still seen to some extent e.g. in Figure 12c. The longer ignition time and lower flame intensity are 
expected to cause a lower temperature near the burner, which also lowers the clinker burning zone temperature. As seen in Figure 10, there is also a slight reduction in the kiln drive power consumption, when the SRF firing is increased to $4.5 \mathrm{t} / \mathrm{h}$. This is also an indication of a lowered temperature in the kiln caused by the SRF.

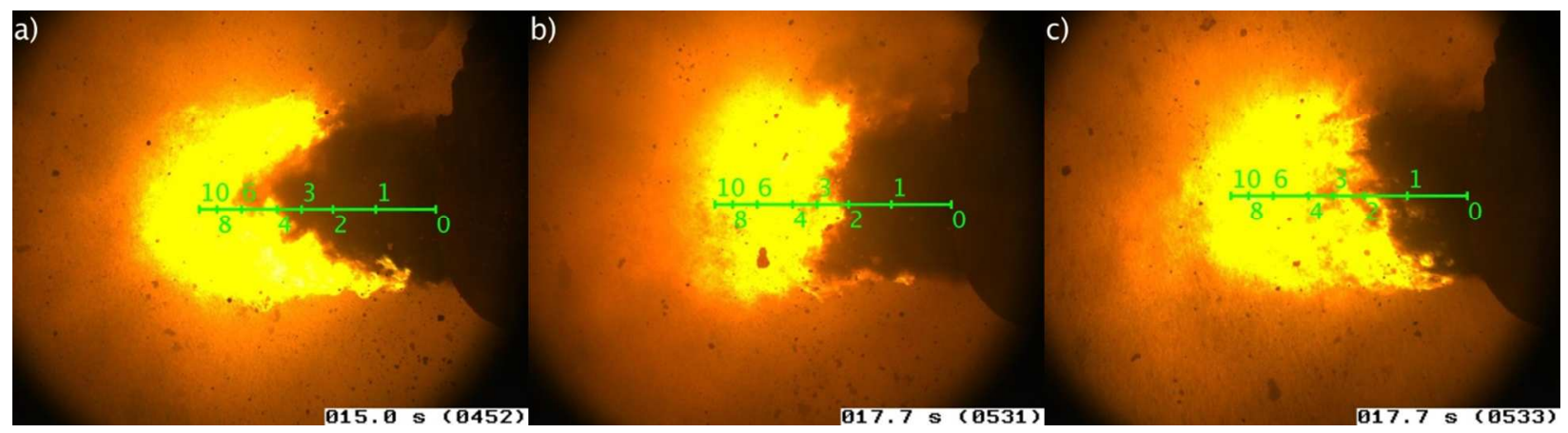

Figure 12: Images of co-firing of coal/petcoke with SRF. $7.5 \mathrm{t} / \mathrm{h}$ coal/petcoke is used with $4.5 \mathrm{t} / \mathrm{h}$ SRF (30\% SRF energy input). Images from Plant 2.

A side by side comparison of the coal/petcoke fired flame and the flame co-fired with SRF is shown in Figure 13. In this figure, the videos have been averaged over 5 seconds. This evens out the turbulent changes, which are observed in Figure 11 and Figure 12 and makes the comparison more straightforward. It becomes evident how the ignition point is moved away from the burner, when SRF is fired and how the intensity of the flame is also lowered, indicating a lower temperature. 


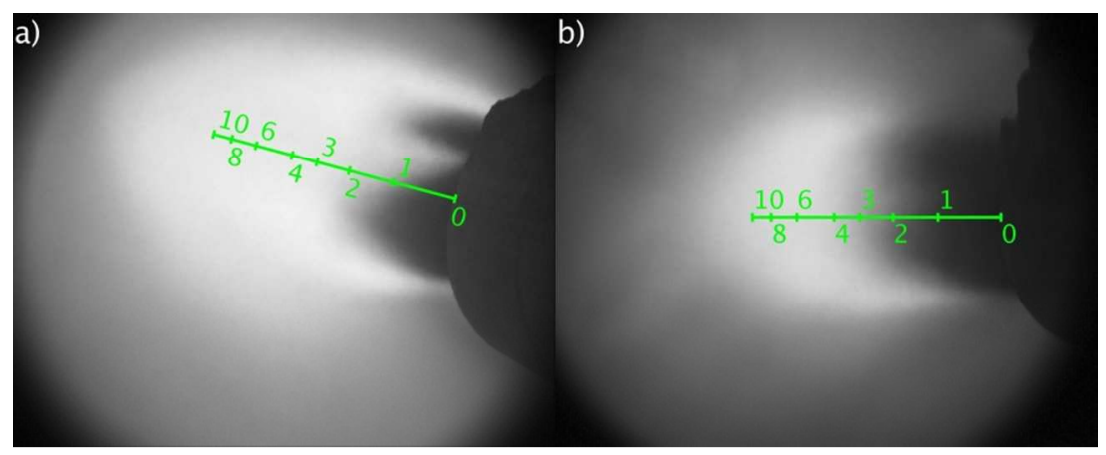

Figure 13: Comparison of the coal/petcoke fired flame (a) with the SRF co-fired flame (b). Images are averaged over 5 seconds. Images from Plant 2.

Figure 14 shows a view under the flame along the wall of the kiln. This is done by turning the camera downwards compared to the normal view used in Figure 11 and Figure 12. This view gives an opportunity to track if particles have dropped out of the flame. During full fossil fuel firing, there is no fuel to be seen outside the flame as indicated in

Figure 14a. When SRF is added to the flame, some particles fall out of the flame and they burn on the wall or charge as shown in

Figure $14 b+c$. Only a very small number of particles are observed to drop out of the flame. It can thus be concluded that most of the SRF stays in the flame, until the particles cannot be tracked any longer due to the limited visibility. However, there are signs that the particles are not fully converted in the flame, and will cause reducing conditions further downstream in the kiln. 


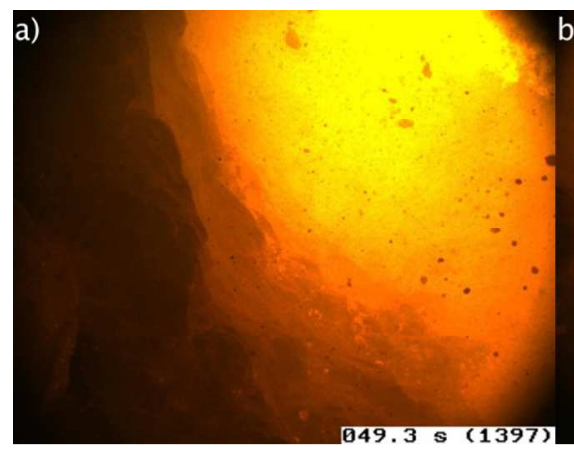

Figure 14: View along the kiln wall and charge under the burner for coal-fired case (a) and cofired case $(b+c)$. The kiln wall is seen in the left side of the images. The kiln bed can be seen on the right side of the images having a more orange color than the wall. Burning particles are bright spots in the images, which have been highlighted with green circles Images from Plant 2.

The high amount of SRF firing, $4.5 \mathrm{t} / \mathrm{h}$, was only upheld for 20 minutes before the amount was reduced to $1.5 \mathrm{t} / \mathrm{h}$. The operator reported an increased dust load during the testing and there were indications of a lower kiln temperature based on the kiln drive power consumption (cf. Figure 10). The increased dust load is presumably caused by local reducing conditions, since the SRF is not fully converted while in suspension. The reducing conditions promote the decomposition of $\mathrm{CaSO}_{4}$ and the evaporation of $\mathrm{SO}_{2}$, which results in recirculation and accumulation of sulfur. ${ }^{13}$ The sulfur creates a separate melt that is immiscible with the main clinker phases and has a low viscosity and surface tension. ${ }^{33}$ It may thus have an adverse effect on the clinker nodulization and increase the dust load, ${ }^{34}$ if too much sulfate melt is present. Excessive dust in the cooler and kiln inhibit the heat transfer and cools the burning zone. ${ }^{35}$ Comparing the images from Plant 2 with those of Plant 1 also show a significantly lower visibility in Plant 2, presumably due to a high dust load. One of the reasons for this is that the kiln manufactures mineralized clinker, where fluoride and sulfur are used as mineralizers/fluxes to lower the burning zone temperature requirement. ${ }^{36,37}$ Mineralized clinker may be burnt at temperatures around $200{ }^{\circ} \mathrm{C}$ lower than 
normal clinker. ${ }^{36}$ This may first appear promising for the use of alternative fuels (AF), which tend to burn at lower temperatures. ${ }^{12}$ However, the mineralized clinker is also more sensitive to process changes $^{38}$ and as observed at Plant 2, even relatively small amounts of AF cannot be handled, due to increased sulfur volatility.

\subsection{Results from Plant 3}

The fuel dosing used during the test day at Plant 3 is shown in Figure 15a and selected process measurements are shown in Figure 15b. Specifically, the measurements include the kiln torque and a number of temperature measurements to indicate the kiln burning zone temperature. The plant uses an infrared pyrometer and thermographic camera to gauge the temperature in the near burner zone of the kiln as well as a thermocouple measuring the temperature in the kiln hood. Initially, the SRF dosing has been $6 \mathrm{t} / \mathrm{h}$, but due to a low temperature in the kiln, at 15:30 the dosing was lowered to $5 \mathrm{t} / \mathrm{h}$ and the petcoke dosing increased. This resulted in a temperature increase, which can be seen by the pyrometer or camera temperature in Figure 15b. The petcoke was deliberately shut off from 16:00 to $16: 30$, in order to better observe the SRF flight behavior in the kiln. In the meantime, gas was used instead to keep the energy input to the kiln constant. 

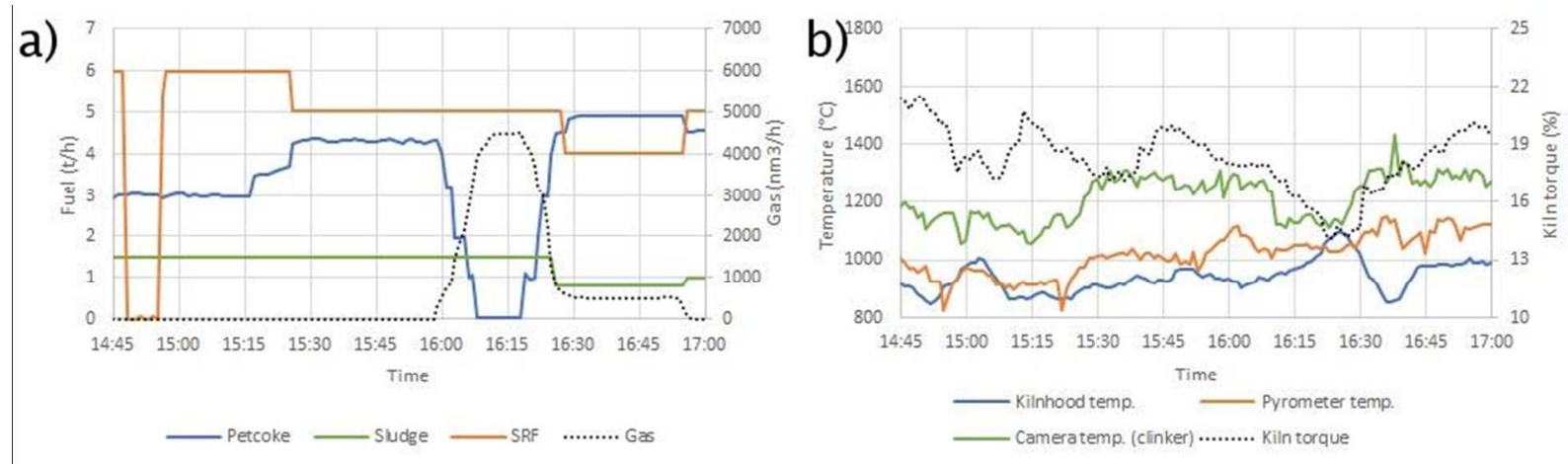

Figure 15: a) Fuel dosing to the kiln burner during the test day. b) Temperatures as measured by pyrometer, thermographic camera, kiln hood thermocouple and the kiln torque during the test day. Gas and kiln torque are plotted on secondary axes. Data from Plant 3.

\subsubsection{Co-fired flame}

The co-fired flame from Plant 3 is shown in Figure 16. It takes approximately 4 meters from the burner tip before the flame is ignited. This is somewhat similar to what was seen in Plant 1 , where petcoke and SRF is also used, while Plant 2 had a very early ignition due to the volatile coal. The images in the figure also underline the large changes that can occur in kiln conditions when firing alternative fuels. The images of Figure $16 \mathrm{~b}$ and c are recorded one hour apart, and the intensity in Figure $16 \mathrm{c}$ is much higher, indicating a higher burning zone temperature. This is caused by increasing the petcoke dosing by $1 \mathrm{t} / \mathrm{h}$ and reducing the SRF dosing by $1 \mathrm{t} / \mathrm{h}$, and the change is also consistent with the higher temperature measurements, as seen in Figure 15. 


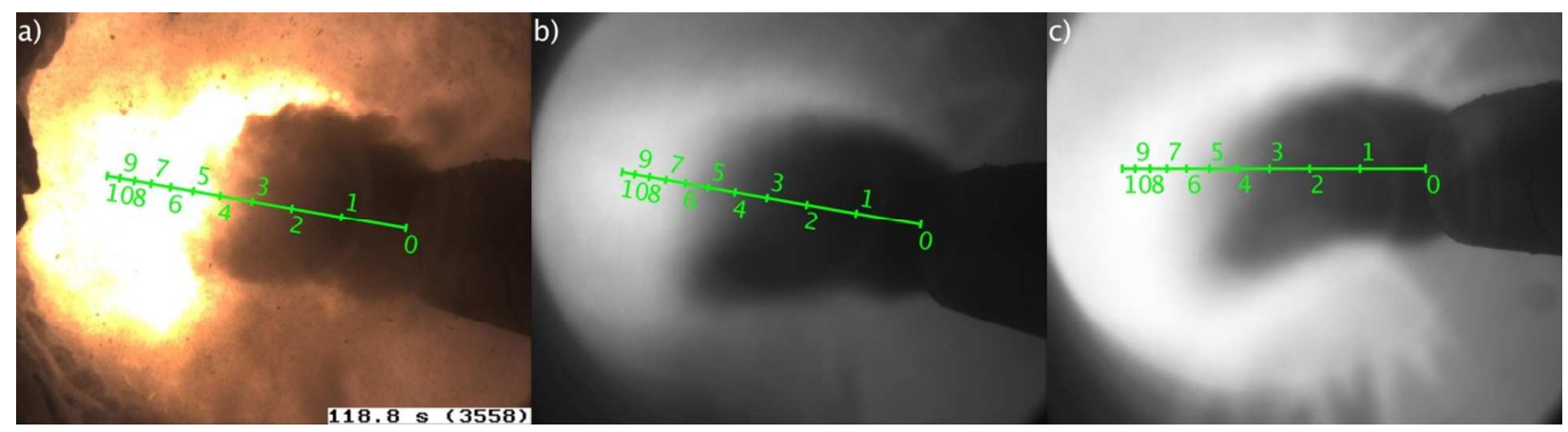

Figure 16: Flame of petcoke co-fired with SRF and sewage sludge. $a+b) 3 \mathrm{t} / \mathrm{h}$ petcoke, $1.5 \mathrm{t} / \mathrm{h}$ sewage sludge, $6 \mathrm{t} / \mathrm{h}$ SRF (60\% AF energy input), recorded at 14:56. c) $4.3 \mathrm{t} / \mathrm{h}$ petcoke, $1.5 \mathrm{t} / \mathrm{h}$ sewage sludge, 5 t/h SRF (45 \% AF energy input), recorded at 15:45. Images from Plant 3.

The flame at Plant 3 is sometimes very divergent compared to Plant 1 and 2, which can cause the flame to impinge on the bed as shown in Figure 17a. This should generally be avoided since it may overheat the refractory and contribute to local reducing conditions. ${ }^{16}$ The design of the burner differs from that used at the other plants. The other burners have separate channels for axial and swirl air, while the Plant 3 burner has only one channel, where the swirl level is adjusted by increasing the tangential angle of the air inlets. If the angle becomes too high, it seems that the burner lacks axial momentum to stabilize the flame, causing a very diverging flame. A relatively small amount of SRF particles are whirled out of the flame close to the burner as also indicated in Figure 17a. Further inside the kiln, just around the point where the petcoke ignites approximately 6 meters from the burner, some burning particles can be observed in the kiln bed, see Figure 17b. In the videos, several burning particles can be seen around this point, which indicates that it is where the SRF particles begin to drop out of the flame. 


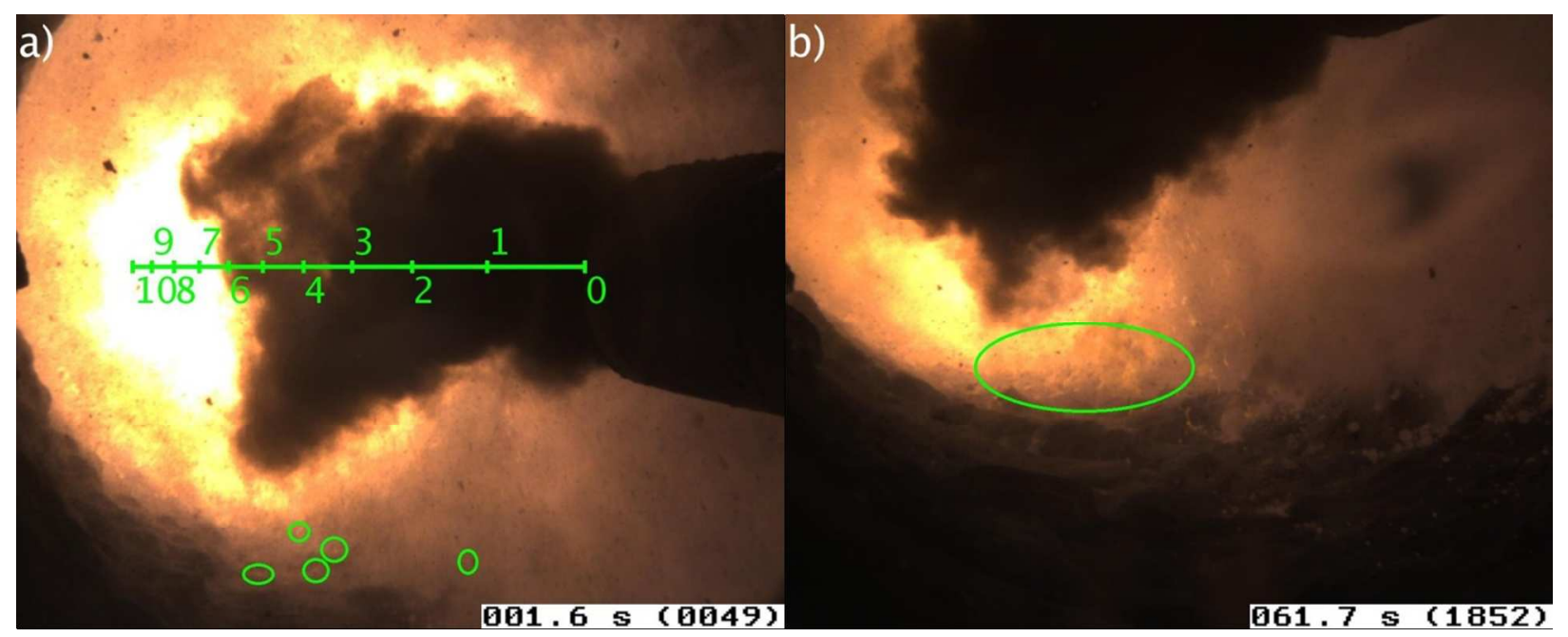

Figure 17: View of the co-fired flame from the side (a) and under the burner (b). Flames in bed are located by green circles. Fuels: 4.3 t/h petcoke, 5 t/h SRF, 1.5 t/h sewage sludge (45 \% AF energy input). Images from Plant 3.

\subsubsection{Flame with Natural Gas}

The SRF is fired though a pipe at the center of the burner, which is surrounded by an annular channel for the injection of petcoke. Similarly to Plant 1 the visibility of the SRF flow is obstructed by the petcoke. In an attempt to understand the SRF flow better the petcoke was turned off for a brief amount of time. To keep the heat input to the kiln, gas was supplied instead, as shown in Figure 15 at around 16:15. While the gas flow is increased, from 0 to approx. 500 $\mathrm{Nm}^{3} / \mathrm{h}$, the ignition point moves closer to the burner tip from approx. 6 meters to 2 meters, cf. Figure 18. The combustion also becomes more intense, with the image becoming more oversaturated. It would seem that this could be quite a viable method to increase the ignitability of the co-fired flame and obtain a high temperature region close to the burner. However, the price of natural gas in most countries will probably make this kind of operation unfeasible. Per unit of energy, gas may be more than four times as expensive as petcoke. ${ }^{39}$ The pyrometer measuring the flame temperature is seen to increase from around $1000{ }^{\circ} \mathrm{C}$ to $1050{ }^{\circ} \mathrm{C}$, with a 
peak at $1100{ }^{\circ} \mathrm{C}$, around the time where the petcoke dosing is lowered. The kiln hood temperature increases in the same period, which also indicates an increased temperature near the kiln outlet. The temperature measured by the kiln camera installed at the plant, however, has a lower reading, while the gas is being fired. The kiln torque is also seen to decrease, which may indicate less heating further inside the kiln. Gas flames normally produce small amounts of soot compared to coal flames, which results in a lower flame emissivity. ${ }^{40}$ The heat transfer from flame to clinker bed can thus be inhibited. This could explain the lower clinker temperatures measured by the camera and the lower kiln torque.

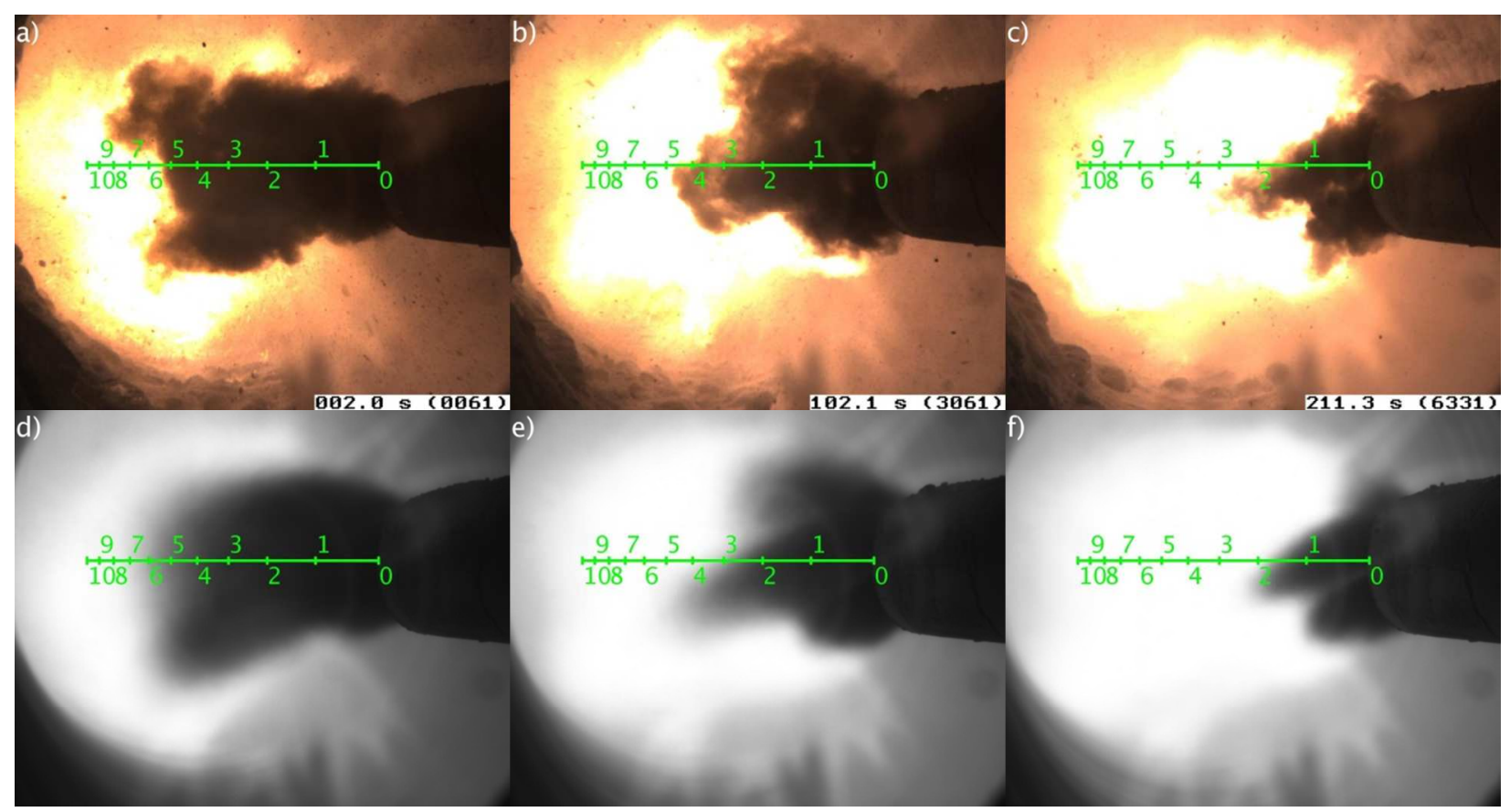

Figure 18: Different flame shapes while the gas flow is increased over 200 seconds from 0 (a+d)

to $500(\mathrm{c}+\mathrm{f}) \mathrm{Nm}^{3} / \mathrm{h}$. Petcoke dosing is constant at $4.3 \mathrm{t} / \mathrm{h}$. Top row shows single frames and bottom row are images averaged over 5 seconds. Images from Plant 3.

Some images of the SRF and gas fired flame without petcoke are shown in Figure 19. The visibility of the SRF changes from frame to frame as shown in the sequence of images in Figure 19, which is mainly due to the natural variations in flame ignition. In Figure $19 \mathrm{~b}$ it is seen that 
the SRF is quite hard to ignite, and it passes at least 6 meters from the burner tip without being ignited, and then disappears in the gas flame. It is very likely to continue further inside before being properly ignited and the conversion in the flame may be low. The SRF is not packed as densely as seen in Plant 1 (cf. Figure 9) when it enters, which is likely due to a lower feeding rate. The dispersion of the SRF appears to be better than for the old burner in Plant 1, and similar to what is achieved for the new burner at Plant 1. A significant amount of small flames can be seen in the bed, in the lower part of the images of Figure 19. This indicates that a large fraction of the SRF may burn in contact with the clinker rather than in suspension.

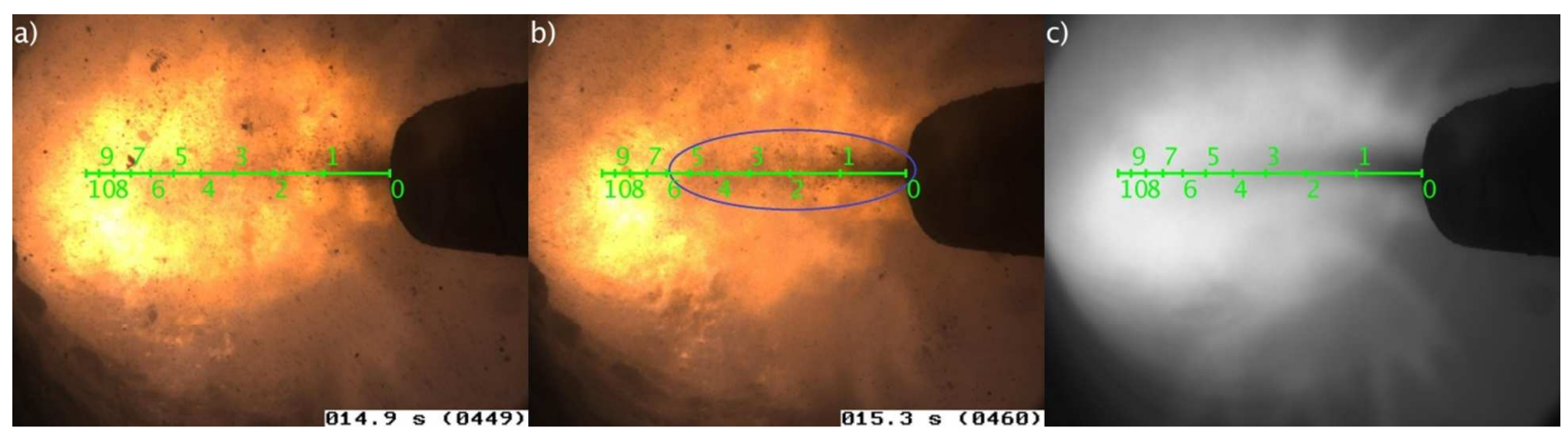

Figure 19: SRF and gas fired flame. $5 \mathrm{t} / \mathrm{h} \mathrm{SRF}, 1.5 \mathrm{t} / \mathrm{h}$ sewage sludge, and $4500 \mathrm{Nm}^{3} / \mathrm{h}$ natural gas (45\% AF energy input). Images from Plant 3.

\subsection{Limiting Factors for Alternative Fuel Firing}

It is highly beneficial to understand the limiting factors for alternative fuel (AF) firing in order to eventually increase the amount of AF firing. Thus, some of the issues encountered at the three plants when firing AF will be discussed in further details here.

Plant 1 fires the highest amount of alternative fuels in the kiln of the three plants studied here. The plant produces clinker with an alite content above $65 \%$, which is a typical level for Portland cement. ${ }^{41}$ Issues with brown clinker or build-ups in the kiln or preheater have not been observed during the measurements with SRF. The plant has a chlorine by-pass and several air blasters are 
installed in the preheater tower to combat build-ups. The main limitation is the lower combustion temperatures obtained during SRF firing. If the SRF firing gets too high, the kiln temperature is lowered. Thus, petcoke is needed to create a high temperature zone to get adequate clinker quality. The petcoke is also used to adjust the burning zone temperature when the SRF heating value or moisture content changes. The plant has previously used oxygen enrichment in the kiln to stabilize the operation at high SRF firing and lower the petcoke consumption. The installation of the new burner has been beneficial for Plant 1. It has been possible to increase the alite content of the clinker, which resulted in increased compressive strength of cement mortar. Furthermore, the substitution with SRF was increased and oxygen enrichment was no longer used. The main difference between the designs of the two burners has been discussed in chapter 3.1, and is related to the mixing intensity achieved by the burners and the ability of the new burner to spread the SRF in the combustion zone.

Plant 2 fires the lowest amount of AF and has a low tolerance. This appears to be mainly caused by the manufacture of mineralized clinker, which is more sensitive to reducing conditions since the sulfur loading is higher than for ordinary clinker. The limit of SRF firing appears to be around $2 \mathrm{t} / \mathrm{h}$, while the plant can tolerate up to $3 \mathrm{t} / \mathrm{h}$ of the granulated tire. In a study by Nielsen et al. ${ }^{42}$, tire granulate was found to be able to release more sulfur from cement raw materials than plastic and wood, which are the main constituents of SRF. Thus, the reason that a higher amount of granulated tires can be tolerated is most likely related to the smaller particle size. This results in a faster conversion of the fuel, resulting in less fuel ending up in the kiln bed to induce reducing conditions.

Plant 3 uses an intermediate amount of alternative fuels in the kiln. The produced clinker has an alite content above $60 \%$ (calculated by Bogue formulas ${ }^{43,44}$ ). Plant 3 sometimes encounters 
problems with reducing conditions, when firing too much alternative fuels. This is seen as brown cores in the cement clinker and some deposit build-ups in the calciner and cement kiln. The plant recently installed a by-pass to reduce the volatile circulation, which is expected to alleviate some of the problems with build-ups, and may allow for a further increase in the use of alternative fuels.

An interesting difference between Plant 1 and Plant 3 is shown in Figure 20. The figure shows the relationship between the fraction of alternative fuels firing at the main burner and the energy input at the main burner and calciner (Hotdisc included) for Plant 1 (Figure 20a) and for Plant 3 (Figure 20b). The data plotted in the figure are based on hourly averages from one month of operation giving a large degree of data scatter. The Pearson correlation coefficient ${ }^{45}$ has been calculated as a measure for the relationship between the variables. Normally, around $60 \%$ of the total fuel used in the cement process will be fired in the calciner and the remainder in the kiln. This is because the calcination of limestone is highly endothermic requiring $1800 \mathrm{~kJ} / \mathrm{kg}{ }^{46}$ This is also the balance at both plants when no AF is fired in the kiln. At Plant 1, the heat input at the burner and calciner is rather independent of the amount of AF fired at the main burner. However, at Plant 3, the energy input at the kiln is increased as the amount of AF in the kiln is increased, while the firing in the calciner is reduced. This shifts the balance between kiln and calciner firing and when high amounts of AF are utilized around $60 \%$ of the energy is fired in the kiln. This indicates that the fuel energy form the $\mathrm{AF}$ is not released quickly enough to contribute to increasing the clinker burning zone temperature, and rather substitutes firing in the calciner. At Plant 1 , the correlation is small, indicating that the fuel fired in the main burner is actually utilized in the kiln. Thus, there are indications that AF burns closer to the kiln exit at Plant 1 than at Plant 3. Nørskov ${ }^{16}$ made some experiments with different injection velocities of AF and found 
that an injection velocity of $30 \mathrm{~m} / \mathrm{s}$ was to be preferred over a velocity of $50 \mathrm{~m} / \mathrm{s}$. The high injection velocity causes the fuel to be injected too far into the kiln, and the energy is not released in a proper location to contribute in rising the clinker temperature. It is possible that a lower injection velocity of AF at plant 3 could ensure that the SRF is not injected too far into the kiln, which allows for the energy to be released in the clinker burning zone.

(a)

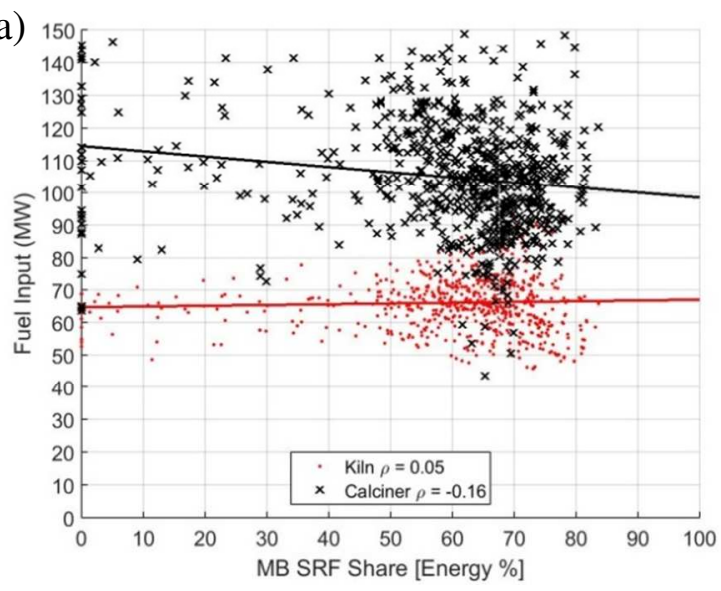

(b)

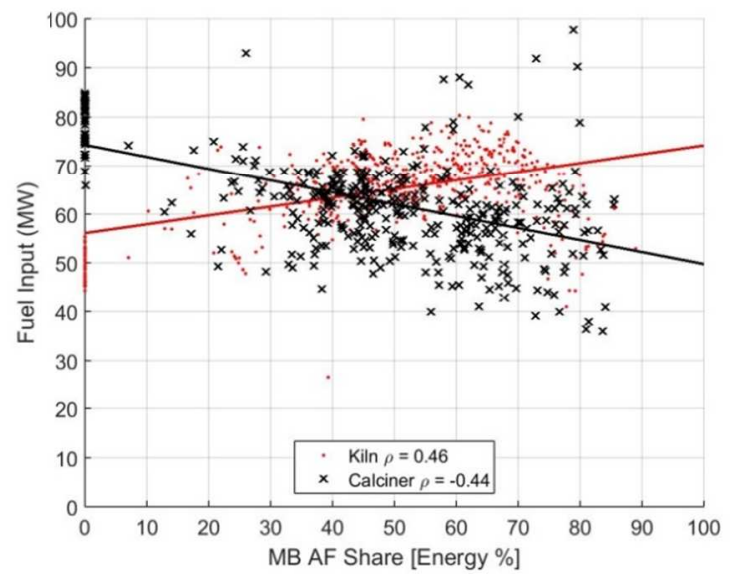

Figure 20: Relationship between the energy from alternative fuels firing at the main burner (MB) and the energy input in the kiln (red dots) and the calciner (black x) for Plant 1 (a) and Plant 3 (b). Data are based on hourly averages for one month of operation. $\rho$ is Pearson correlation coefficient.

Another large difference between the plants is their tolerance to reducing conditions. At Plant 1 neither brown clinker or deposits were observed during testing, at Plant 2 the dust load in the kiln is increased when utilizing high amounts of AF due to sulfur evaporation, and at Plant 3 brown clinker and deposits are sometimes encountered. The difference may largely be caused by the sulfur evaporation in the kiln. The sulfur evaporation may be limited if there is a high amount of alkalis in the clinker, since alkali sulfates are less volatile than calcium sulfate. One measure is the sulfur modulus calculated as: ${ }^{47}$ 
The sulfur modulus calculated for the clinker of the three plants is on average $0.64,1.51$, and 0.84. A value around 1 is adequate to ensure that there is sufficient alkali to combine with the sulfur. ${ }^{47}$ It can thus be seen that Plant 2 operates at a high sulfur modulus, due to the high input of sulfur in the mineralized clinker, but this also means that it is more susceptible to sulfur evaporation caused by reducing conditions. The sulfur modulus for Plant 1 and Plant 3 are low enough that most of the sulfur should be able to combine with alkalis. However, comparing the fuels of Plant 1 and 3, cf. Table 1, it is seen that the sulfur content of the petcoke used in Plant 3 is higher than that in Plant 1 and the chlorine content of the SRF is higher. The plant will thus have a higher input of sulfur and chlorine though the fuel, which may set a limit for the utilization of alternative fuels. In addition, Plant 3 did not have a by-pass to lower the amount of recirculating species. Thus, Plant 3 is likely to be more vulnerable to reducing conditions causing sulfur evaporation and deposits than Plant 1.

Brown core clinker is also sometimes encountered at Plant 3. The brown color is caused by a reduction of $\mathrm{Fe}^{3+}$ to $\mathrm{Fe}^{2+}$, which may substitute $\mathrm{MgO}$ in the ferrite phase $\left(\mathrm{C}_{4} \mathrm{AF}\right)$, which otherwise gives cement its dark grey color. The reduced iron can also affect the formation of alite, lowering the cement quality. ${ }^{28-30}$ Alternative fuels are burned in contact with the bed in both Plant 1 and Plant 3, but Plant 1 tolerates it better, with no formation of brown clinker. It may be related to where the AF mainly burns, which was discussed above and illustrated in Figure 20. If the AF burns too far inside the kiln it may drop into a bed of un-nodulized clinker, with a large surface area which may be more prone to iron reduction. ${ }^{27}$ If the AF mainly burns close to the burner where the nodules have already formed, the surface area for evaporation of 
sulfur and iron reduction is significantly smaller and the oxygen concentration will be higher. The brown clinker cores may also be related to the rate of clinker cooling. Locher $^{29}$ showed that the adverse effects of burning under reducing conditions could be limited by a rapid cooling from $1250{ }^{\circ} \mathrm{C}$ in air. Perhaps high clinker porosity will be beneficial to counter brown cores, since it will help oxygen to diffuse in and reoxidize the clinker during cooling.

In summary, all three plants are limited by the conversion rate of the alternative fuels. For Plant 1 the main limitation is that the AF does not burn quickly enough to obtain sufficiently high temperatures. Thus, some petcoke is needed to maintain a high temperature and proper heat transfer to the clinker. At Plant 2 and Plant 3 the main limitation is that the fuel is not converted quickly enough before ending in the bed, eventually leading to localized reducing conditions in the kiln. It would be interesting to study if the utilization could be improved by drying or milling of SRF to obtain faster conversion of the fuel. Excess heat typically available in the off-gasses could be used to dry alternative fuels, but milling of SRF is difficult due to the soft paper and plastic fractions ${ }^{48}$ and impurities that may damage the mill.

\section{Conclusions}

A specially developed camera setup has been used to study the kiln flames at 3 different cement plants. The probe was designed so it could be inserted directly in the cement kiln hood where the temperature is around $1000{ }^{\circ} \mathrm{C}$ and the dust load is high. This allowed for a detailed study of the influence of alternative fuels on the cement kiln flame.

An overview of the flames studied at the three different cement plants is given in

Table 4. Adding alternative fuel to the flame had at all three cement plants a negative impact on the flame. At Plant 1 the ignition point was between 3-4 meters from the burner tip when petcoke was fired alone, and when SRF was added to the flame the ignition point was between 5- 
6 meters from the burner tip. At Plant 3 the ignition point was at a similar distance while cofiring petcoke and SRF. The flame at Plant 2 ignited within 1 meter. A mix of coal and petcoke was used, which ignites more readily than the petcoke at Plant 1 and 3 due to a higher volatile content of the coal. At Plant 2 the ignition point was also shifted approx. 2 meters when SRF was added to the flame. At all three plants, the flame intensity was also lowered when using AF, which indicates a lower combustion temperature. This is mainly due to the high moisture content and large particle size of alternative fuels compared to conventional fuels, which results in a lower conversion rate of the fuel. At Plant 2 and Plant 3 measurements of the kiln drive power consumption also suggested that the temperature in the kiln was decreased when co-firing AF. The lower temperatures in the kiln may negatively affect the clinker quality.

Table 4: Overview of the impact of alternative fuels on the flame ignition point at the three cement plants. C: Coal, PC: Petcoke, SRF: Solid Recovered Fuel, SS: Sewage Sludge

\begin{tabular}{|c|c|c|c|c|c|c|c|c|}
\hline & \multicolumn{4}{|c|}{ Plant 1} & \multicolumn{2}{|l|}{ Plant 2} & \multicolumn{2}{|l|}{ Plant 3} \\
\hline & \multicolumn{2}{|c|}{ Old Burner } & \multicolumn{2}{|c|}{ New Burner } & & & & \\
\hline Flame & Fossil & $\begin{array}{l}\text { Co- } \\
\text { fired }\end{array}$ & Fossil & $\begin{array}{l}\text { Co- } \\
\text { fired }\end{array}$ & Fossil & $\begin{array}{l}\text { Co- } \\
\text { fired }\end{array}$ & $\begin{array}{l}\text { Co- } \\
\text { fired } 1\end{array}$ & $\begin{array}{l}\text { Co- } \\
\text { fired } 2\end{array}$ \\
\hline Figure & $6 a+b$ & $7 a+b$ & $6 c+d$ & $7 c+d$ & $\begin{array}{l}11+13 \\
a\end{array}$ & $\begin{array}{l}12+13 \\
b\end{array}$ & $16 \mathrm{c}$ & $18 c+f$ \\
\hline $\begin{array}{l}\text { Fuel } \\
(\mathrm{t} / \mathrm{h})\end{array}$ & - & - & - & - & $\begin{array}{l}\text { PC: } 2.1 \\
\text { C: } 8.4 \\
\text { SRF: } 0\end{array}$ & $\begin{array}{l}\text { PC: } 1.5 \\
\text { C: } 6 \\
\text { SRF: } \\
4.5\end{array}$ & $\begin{array}{l}\text { PC: } 4.3 \\
\text { SRF: } 5 \\
\text { SS: } 1.5\end{array}$ & $\begin{array}{l}\text { PC: } 4.3 \\
\text { SRF: } 5 \\
\text { SS: } 1.5 \\
\text { Gas: } \\
500 \\
\mathrm{Nm}^{3}\end{array}$ \\
\hline $\begin{array}{l}\text { AF } \\
\text { Energy }\end{array}$ & 0 & 80 & 0 & 70 & 0 & 30 & 45 & 45 \\
\hline
\end{tabular}




\begin{tabular}{|l|l|l|l|l|l|l|l|l|}
\hline $\begin{array}{l}\text { Share } \\
(\%)\end{array}$ & & & & & & & & \\
\hline $\begin{array}{l}\text { Ignitio } \\
\text { n Point } \\
(\mathrm{m})\end{array}$ & $>4$ & $>5$ & $3-4$ & $\sim 5$ & $1-2$ & $2-4$ & $\sim 4$ & $\sim 2$ \\
\hline
\end{tabular}

At all three plants, it was observed how some of the SRF drops out of the flame and burns in contact with the cement clinker. At Plant 2 and 3 this leads to problems with sulfur evaporation or brown cored clinker, while Plant 1 appears to be more robust to local reducing conditions. Why this is the case is not fully understood, but Plant 2 is sensitive to reducing conditions due to manufacturing mineralized clinker and has a low Alkali-Sulfur Ratio, which makes sulfur evaporation more probable. For Plant 1 and Plant 2 there may be a difference in where the SRF mainly burns or there could be a difference in the cooling which can prevent reduced clinker.

The burner design does have a significant influence on the flame. The burner design at Plant 2 could create ignition sources, by allowing secondary air to be entrained into the fuel stream in a few locations. A clear difference in the two burner designs tested at Plant 1 was observed. The change from an annular axial air channel to axial air jets benefited the ignition when using petcoke. The design of the swirl channel influences the flame swirl level, increasing the dispersion of SRF particles in the flame. The old burner at Plant 1 had very little dispersion of the SRF. This creates a cold core of SRF in the flame, which will be difficult to ignite and the SRF will continue far into the kiln and eventually land in the clinker bed, likely largely unconverted. Alternatively, the SRF can be spread as much as possible, which occurs with the new burner at Plant 1. This will evidently result in more SRF dropping out of the flame and ending up in the clinker bed close to the burner. On the other hand, the energy in the fuel will be released earlier, contributing better to maintain a high temperature in the clinker burning zone. 
Based on the results presented here, the second option with a high degree of fuel dispersion appears beneficial. It may also reduce the problems with localized reducing conditions induced by fuel in the bed, since the fuel will be in contact with nodulized clinker, which has a relatively small surface area, in the part of the kiln where the oxygen concentration is highest. By changing the burner at Plant 1, it was possible to increase the alite content of the clinker while increasing the substitution of SRF. 


\section{ASSOCIATED CONTENT}

Selected videos from the three plants

Description of distance estimation in images

\section{AUTHOR INFORMATION}

\section{Corresponding Author}

* E-mail address: monepe@kt.dtu.dk.

\section{Present Addresses}

$†$ Dall Energy, Venlighedsvej 2, 2970 Hørsholm, Denmark

\section{ACKNOWLEDGMENT}

The work of this article is established within the framework of the advanced technology platform "Minerals and Cement Process Technology" funded by the Danish National Advanced Technology Foundation, FLSmidth A/S, Hempel A/S, and the Technical University of Denmark. The authors wish to thank our industrial collaborators, who have allowed us to do measurements at their plants. The help of Jens Henry Poulsen of DTU who manufactured the video probes used for this study is highly appreciated. Christian Andersen of FLSmidth A/S who helped during measurements is also thanked.

\section{ABBREVIATIONS}

AF, Alternative Fuel; ASR, Alkali-Sulfur Ratio; C, Coal; MB, Main burner; PC, Petcoke; SRF, Solid Recovered Fuel; SS, Sewage Sludge 


\section{REFERENCES}

(1) Sarc, R.; Lorber, K.; Pomberger, R.; Rogetzer, M.; Sipple, E. Waste management \& research 2014, $32(7), 565-585$.

(2) Mokrzycki, E.; Uliasz- Bochenczyk, A. Applied Energy 2003, 74 (1-2), 95-100.

(3) Usón, A. A.; López-Sabirón, A. M.; Ferreira, G.; Llera Sastresa, E. Renewable and Sustainable Energy Reviews 2013, 23, 242-260.

(4) Larsen, M. B. Alternative Fuels in Cement Production, PhD Thesis, Technical University of Denmark: Kgs. Lyngby, Denmark, 2007.

(5) Velis, C. A.; Longhurst, P. J.; Drew, G. H.; Smith, R.; Pollard, S. J. T. Critical Reviews in Environmental Science and Technology 2010, 40 (12).

(6) Krüger, B.; Mrotzek, A.; Wirtz, S. Waste Management 2014, 34 (2), 390-401.

(7) Wirthwein, R.; Emberger, B. Cement International 2010, 8 (4), 42-46.

(8) Liedmann, B.; Arnold, W.; Krüger, B.; Becker, A.; Krusch, S.; Wirtz, S.; Scherer, V. Fuel 2017, 200, 252-271.

(9) Vainikka, P.; Bankiewicz, D.; Frantsi, A.; Silvennoinen, J.; Hannula, J.; Yrjas, P.; Hupa, M. Fuel 2011, 90 (5), 2055-2063.

(10) Dunnu, G.; Hilber, T.; Schnell, U. Energy \& Fuels 2006, 20 (4), 1685-1690.

(11) Emberger, B.; Hoenig, V. Cement International 2011, 9 (5), 48-60. 
(12) Hiromi Ariyaratne, W. K.; Malagalage, A.; Melaaen, M. C.; Tokheim, L.-A. International Journal of Modeling and Optimization 2014, 4 (4), 263-272.

(13) Cortada Mut, M. D. M.; Nørskov, L. K.; Frandsen, F. J.; Glarborg, P.; Dam-Johansen, K. Energy and Fuels 2015, 29 (7), 4076-4099.

(14) D'Hubert, X. Global Cement Magazine 2017, No. February, 12-23.

(15) D'Hubert, X. Global Cement Magazine 2017, No. March, 10-18.

(16) Nørskov, L. K. Combustion of solid alternative fuels in cement kiln burners, $\mathrm{PhD}$ Thesis, Technical University of Denmark, 2012.

(17) Schmidt, D. In 2007 IEEE Cement Industry Technical Conference Record; IEEE, 2007; pp 140-146.

(18) Lin, B.; Jørgensen, S. B. Journal of Process Control 2011, 21 (4), 547-553.

(19) Verein Deutscher Zementwerke (VDZ). VDZ Activity Report 2005-2007; Düsseldorf, Germany, 2008.

(20) Nobis, R. H. IEEE Transactions on Industry Applications 1991, 27 (5), 798-806.

(21) Vaccaro, M. H. IEEE-IAS/PCS 2002 Cement Industry Technical Conference. Conference Record 2002, No. May, 265-270.

(22) Mullinger, P. J.; Jenkins, B. G. World Cement 1987, No. 2, 48-56.

(23) Roy, G. World cement 2002, 33 (4).

(24) Wagner, A. Cement International 2004, 2, 88-97. 
(25) Lowes, T. M.; Evans, L. P. Zement-Kalk-Gips 1993, No. 12, 761-768.

(26) Chigier, N. A. Astronautica Acta 1972, 17, 387-395.

(27) Choi, G.-S.; Glasser, F. Cement and Concrete Research 1988, 18 (3), 367-374.

(28) Long, G. R. Philosphical Transactions of the Royal Society A 1983, 310, 43-51.

(29) Locher, F. W. World Cement Technology 1980, 11 (2), 67-73.

(30) Ichikawa, M.; Komukai, Y. Cement and Concrete Research 1993, 23 (4), 933-938.

(31) Young, G. L.; Miller, F. M. In Innovations in Portland Cement Manufacturing; Bhatty, J. I., Miller, F. M., Kosmatka, S. H., Bohan, R. P., Eds.; Portland Cement Association: Skokie, Illinois, USA, 2011; pp 311-342.

(32) Moles, F. D.; Watson, D.; Lain, P. B. Journal of the Institute of Fuel 1973, 353-362.

(33) Borgholm, H. E.; Herfort, D.; Rasmussen, S. World Cement 1995, No. 8, 27-33.

(34) Petersen, I. F.; Johansen, V. Cement and Concrete Research 1979, 9 (5), 631-639.

(35) Tackie, E. N.; Watkinson, A. P.; Brimacombe, J. K. The Canadian Journal of Chemical Engineering 1989, 67, 806-817.

(36) Moir, G. K. Philosophical Transactions of the Royal Society A: Mathematical and Physical 1983, 310 (1511), 127-138.

(37) Emanuelson, A.; Hansen, S.; Viggh, E. Cement and Concrete Research 2003, 33 (10), $1613-1621$.

(38) Bhatty, J. I. Use of Fluxes and Mineralizers in the Cement Industry: A Survey.; 1996. 
(39) Greco, C.; Picciotti, G.; Greco, R. M.; Ferreira, G. M. In Innovations in Portland Cement Manufacturing; Bhatty, J. I., Miller, F. M., Kosmatka, S. H., Bohan, R. P., Eds.; Portland Cement Association: Skokie, Illinois, USA, 2011; pp 239-308.

(40) Hewlett, P. C. Lea's Chemistry of Cement and Concrete, 4th ed.; Butterworth-Heinemann, 1998.

(41) Schorct, F.; Kourti, I.; Scalet, B. M.; Roudier, S.; Sancho, L. D. Best Available Techniques (BAT) Reference Document for the Production of Cement, Lime and Magnesium Oxide; Sevilla, Spain, 2013.

(42) Nielsen, A. R.; Larsen, M. B.; Glarborg, P.; Dam-Johansen, K. Energy \& Fuels 2011, 25 (9), 3917-3924.

(43) Bogue, R. H. Industrial and Engineering Chemistry Analytical Edition 1929, 1 (4), 192197.

(44) Taylor, H. F. W. In Cement Chemistry; Thomas Telford, 1997.

(45) Benesty, J.; Chen, J.; Huang, Y.; Cohen, I. In Noise Reduction in Speech Processing; Springer: Berlin, 2009; Vol. 2, pp 37-40.

(46) CRC Handbook of Chemistry and Physics, 97th ed.; Haynes, W. M., Ed.; CRC Press, 2016.

(47) Theisen, K.; Jøns, E.; Osbæck, B. In Innovations in Portland Cement Manufacturing; Bhatty, J. I., Miller, F. M., Kosmatka, S. H., Bohan, R. P., Eds.; Portland Cement Association: Skokie, Illinois, USA, 2011; pp 365-400. 
(48) Maier, J.; Gerhardt, A.; Dunnu, G. In Solid Biofuels for Energy; Grammelis, P., Ed.; Springer: London, 2011; pp 75-94. 